\title{
COLD PROGRESSION AND ITS EFFECTS ON INCOME DISTRIBUTION
}

\author{
BURKHARD HEER \\ BERND SÜSSMUTH
}

CESIFO WORKING PAPER NO. 951

CATEGORY 6: MONETARY POLICY AND INTERNATIONAL FInANCE

MAY 2003

\footnotetext{
An electronic version of the paper may be downloaded

- from the SSRN website: www.SSRN.com

- from the CESifo website: www.CESifo.de
} 


\title{
COLD PROGRESSION AND ITS EFFECTS ON INCOME DISTRIBUTION
}

\begin{abstract}
We present new empirical evidence for the US economy that inflation reduces the inequality of the earnings distribution. The main mechanism emphasized in this paper is the tax income bracket effect. Governments only adjust the nominal income tax brackets slowly to a rise in prices, typically less often than once every other year in the US post-war history. We also develop a theoretical general equilibrium monetary model with income heterogeneity. In this model, the effect of higher inflation on income distribution is shown to be rather small. However, we find that a longer duration between two successive adjustments of the income tax schedule reduces employment, savings, and output significantly.
\end{abstract}

JEL Code: D31, E31, E44, E52.

Keywords: cold progression, inflation, income distribution, tax income brackets.

\author{
Burkhard Heer \\ University of Bamberg \\ Department of Economics \\ Feldkirchenstrasse 21 \\ 96052 Bamberg \\ Germany \\ burkhard.heer@sowi-uni-bamberg.de
}

\author{
Bernd Süssmuth \\ University of Bamberg \\ Department of Economics \\ Feldkirchenstrasse 21 \\ 96052 Bamberg \\ Germany
}

bernd.suessmuth@sowi-uni-bamberg.de 


\section{Introduction}

The literature discusses several channels through which inflation may alter income, earnings, or wealth distributions. Among others, these channels include differential indexation of wages across income groups, disproportionally allocated subsidized loans, and the TanziOlivera effect on taxes and governmental revenues. The "bracket creep effect," i.e. the inflation-induced increase in marginal income taxes in case of less than fully or infrequently adjusted tax brackets, is also a major cited culprit for deteriorating effects on the income distribution.

There is a well-known early strand of literature representing a broad empirical research effort aimed to contribute information on the (re-)distributional effects of inflation on the US income and/or wealth distribution. It includes the works of Bach and Ando (1957), Budd and Seiders (1971), Bach and Stephenson (1974), and Wolff (1979). With some exceptions $^{1}$ this literature either (i) underlies a detailed disaggregate definition of wealth and discriminates a set of different income types (notably before taxes) and portfolios of different demographic groups of households, business and governmental sectors, etc. or (ii) investigates the effects of inflation determined by market forces and by public and private transfer policies, before any subsequent distribution through personal income tax. In contrast to this, we here explicitly focus on the latter and concentrate on individual income after taxes as our primary income type of interest. So far as we know, quantitative work on this topic is still rather thin if not to say a neglected issue hitherto.

The present paper contributes to the literature in quantitatively assessing bracket creep effects of inflation on the base of US data and providing novel insights. Our findings are based on techniques starting from different methodological premises: We begin our study investigating time series evidence of the relationship between the US inflation rate and income distributional measures. The applied techniques range from traditional BlinderEsaki-Schultz (BES-) type single-equation regression models to the estimation of impulse

\footnotetext{
${ }^{1}$ Bach and Ando (1957) and Bach and Stephenson (1974) see taxpayers as the main beneficaries of inflation if it is assumed that debt will be paid off by collections from taxpayers and therefore the latter can be seen as "indirect debtors." They argue that if debt in form of governmental interest charges is repaid by taxation, inflation redistributes real purchasing power in favor of the higher income groups since these were slightly heavier taxpayers than federal bondholders in the early and mid 1950s and early 1970s. See Bach and Ando (1957), p. 5-7, and Bach and Stephenson (1974), p. 2-7.
} 
responses based on vector error correction models.

In addition, we develop a monetary general equilibrium model of progressive income taxation in order to study the effects of cold progression. While the individual agents face idiosyncratic risk with regard to their productivity, there is no aggregate uncertainty in the economy as the government adjusts its tax schedule in a deterministic way and the money grows at an exogenous and constant rate. In response to a higher inflation or a longer duration of the cold progression, individuals face higher income taxes, both on average and marginally as the US income tax is progressive. As a consequence, agents adjust their labor supply and savings decision. Surprisingly, agents do not change their behavior significantly between periods. However, if we consider a tax policy regime that adjusts the tax schedule for inflation more frequently, we find that agents increase both their labor supply and savings markedly compared to a system with less frequent adjustments. We, therefore, carefully conclude that the inflation rate is a less important phenomenon for the effects of cold progression compared to the duration of cold progression, i.e. the length of the time period between two successive income tax schedule adjustments for inflation.

The remainder of the paper is structured as follows. Section 2 presents empirical evidence for the US. Section 3 introduces the overlapping-generations model with two assets, money and equity. The model is calibrated with regard to the characteristics of the US economy in section 4. Our numerical results are presented in section 5. Section 6 concludes.

\section{Empirical analysis}

\section{$2.1 \quad$ Data}

For our empirical study of the present section, data on the US income distribution from 1951 to 1991 are taken from the popular Deininger and Squire (1996) data set (considering "accept" values only). ${ }^{2}$ The contained time series are extensively documented in Deininger and Squire (1996) and are ultimately based on data provided by the US Census Bureau, published in its Current Population Reports. Apart from its frequent use in empirical

\footnotetext{
${ }^{2}$ Data are downloadable at: http://www . worldbank.org/research/growth/dddei squ.htm. Note, we de-cumulated the quintile income shares, given as cumulative figures in the original data set.
} 
studies (cf. Romer and Romer, 1998), this data set seems suitable for our aims, inasmuch it offers information on a relatively longer time period than, e.g., the series directly provided in the 'Historical Income Tables' by the US Census Bureau, ranging from 1966 to 1999. Time series on the US unemployment and inflation rate (the latter based on CPI data) are taken from the databases of the Bureau of Labor Statistics and the IMF (International Financial Statistics), respectively.

As documented, e.g., by Auerbach and Feenberg (2000), our observation period incorporates a number of major legislative changes in the individual income tax. These include: the Revenue Act of 1964, which reduced the top marginal income rate from 91 to $71 \%$; the Tax Reform Act of 1969, which introduced a ceiling of $50 \%$ on the marginal tax rate on "earned" income; the Economic Recovery Tax Act of 1981, which reduced the top marginal rate on other income from 70 to $50 \%$, and finally the Tax Reform Act of 1986, which reduced the marginal rate on the highest incomes to $28 \%$ and the top marginal rate to $33 \%$. For the period 1951-86, the US tax system may be described as being based on nominal income and deductions, i.e., not indexed to the overall price level, as a system for which inflation raises the real value of taxes paid for any given level of real income, because the system is progressive with respect to nominal income. Therefore, during this period an individual with a given real income will appear "wealthier" and face a higher average tax burden. By the mid 1980s, the US tax system became effectively inflation-indexed when provisions that indexed rate brackets, personal exemptions and the so called "standard deduction" took effect; ${ }^{3}$ see Auerbach and Feenberg (2000), p. 4-6. Apart from these major legislative changes, several partial and substantial changes of tax bracket boundaries $(T B B)$ and of regular tax rates for fixed tax bracket boundaries $(T R B)$ took place. A comprehensive survey along with the detailed construction of our total tax brackets effect $(T T B=T B B+T R B)$ variable based on publications of the Department of the Treasury, Internal Revenue Service (henceforth IRS), and the US Major Tax Guide is given in the appendix. Accordingly, for the period 1951-91 (1951-86) the US economy experienced changes of $T B B$ on average every 2.93 (4.00) years, $T R B$-changes every 2.93 (3.60) years, and TTB-effects every 1.95 (2.25) years.

\footnotetext{
${ }^{3}$ These provisions were actually enacted already in 1981 as part of the Economic Recovery Act, but delayed in their implementation.
} 


\subsection{Evidence based on regressions of the BES-type}

The traditional empirical model by Schultz (1969) characterizes the relationship between the Gini coefficient of the income distribution $(G)$ and inflation $(\pi)$ as follows

$$
G_{t}=\beta_{0}+\beta_{1} \pi_{t}+\beta_{2} u_{t}+\sum_{i=3}^{n} \beta_{i} f^{n}(t)+\varepsilon_{t}
$$

i.e. as a linear function of (i) a constant $\beta_{0}$, referring to a component of the Gini coefficient that is autonomous with regard to the explanatories, (ii) the level of contemporaneous inflation $\pi_{t}$, (iii) the current overall unemployment rate $u_{t}$, and (iv) a trend function $\sum_{i=1}^{n} f^{n}(t)$, separating secular from cyclical influences on income distribution ${ }^{4}$ plus an i.i.d. normal error vector $\varepsilon_{t}$. Some ten years later, Blinder and Esaki (1978) extended this basic strategy by additionally considering relative income shares of different segments of the population as endogenous variables:

$$
Q_{j, t}=\beta_{0}+\beta_{1} \pi_{t}+\beta_{2} u_{t}+\sum_{i=3}^{n} \beta_{i} f^{n}(t)+\varepsilon_{t},
$$

where $Q_{j, t}$ denotes the share of the $j$ th quintile $(j=1, \ldots, 5)$ in the distribution of income among households in the $t$ th year. This specification allows to estimate whether "side effects" of inflation change the relative income position of the different income groups of the society at stake. Contrary to the Schultz-specification, where inflation is expected to decrease income inequality in the presence of "cold progression" (i.e. a negative coefficient resultant for the inflation rate), the Blinder-Esaki-model does not predict a specific sign pattern. The signs of the coefficients are rather dependent on institutional characteristics, like the relative distribution of non-indexed financial assets and liabilities across income groups, particular groups' ability to anticipate price shocks, etc. By considering $u_{t}$, specifications (1) and (2) implicitly test whether macroeconomic policies, including but not limited to financial policies, which impact on unemployment, will also have an impact on the distribution of income across households.

\footnotetext{
${ }^{4}$ Originally, this trend function was linearly specified $(n=1)$. However, we also employ more adequate polynomial trend functions $(n=2)$. To check the estimation results of the present subsection for robustness, we alternatively also consider smooth trend functions, as extracted from the orignial dependent series by means of the HP(100) and HP(6.25) highpass-filters; see Hodrick and Prescott (1997) and Ravn and Uhlig (2002).
} 
Several variants of these specifications have been estimated since its establishment as the "standard model" in the area of single-country time series studies on the effects of inflation on income distribution in the 1980s. ${ }^{5}$ They became to be known as Blinder-Esaki-Schultz (BES-) type regressions. In the following, we will consider modified versions of specifications (1) and (2) that

(a) allow for a non-monotone relationship between the income distributional measures (of inequality) and inflation, and

(b) take major legislative changes, historical tax bracket adjustments, and changes in the relative tax rate for the US income tax into account.

In the course of modification (a), we have a special interest in quantitatively assessing a non-linear (potentially convex) relationship between our distributional measures $\left(G_{t}\right.$, $\left.Q_{j, t}\right)$ and the inflation rate $\left(\pi_{t}\right)$. This stems from the fact that given there is a significant convex relationship, we will be able to determine a threshold value $\pi^{*}$ that quantifies the critical inflation rate above which the progressive effect of inflation turns into a regressive one. Values of $\pi>\pi^{*}$ would then indicate an increasing inequality in the distribution of household incomes with every marginal increase in inflation. Formally, we consider the following basic specifications

$$
\begin{aligned}
G_{t} & =\beta_{0}+\left(\beta_{1}+\beta_{2} D_{t}\right) \pi_{t}+\left(\beta_{3}+\beta_{4} D_{t}\right) \pi_{t}^{2}+\beta_{5} u_{t}+\sum_{i=6}^{n} \beta_{i} f^{n}(t)+\varepsilon_{t}, \\
Q_{j, t} & =\beta_{0}+\left(\beta_{1}+\beta_{2} D_{t}\right) \pi_{t}+\left(\beta_{3}+\beta_{4} D_{t}\right) \pi_{t}^{2}+\beta_{5} u_{t}+\sum_{i=6}^{n} \beta_{i} f^{n}(t)+\varepsilon_{t},
\end{aligned}
$$

where $j=1, \ldots, 5$ and $D_{t}$ denotes a dummy variable for $t=1, \ldots, T . D_{t}$ takes on values of 1 for historical tax bracket boundaries adjustments and/or changes of the "regular" income tax rate for given boundaries - a value of 0 else. For detail on the construction of this binary variable and its different definitions for the post-World War (WW) II US economy, the reader is referred to the appendix. From (3), it can be easily seen that

$$
\pi^{*}=-\beta_{1} /\left(2 \beta_{3}\right)
$$

\footnotetext{
${ }^{5}$ A survey of these early studies is given, e.g., by Bulir and Gulde (1995).
} 
in the case of abstracting from income tax adjustments ${ }^{6}$ and

$$
\pi^{*}=-\left(\beta_{1}+\beta_{2}\right) /\left[2\left(\beta_{3}+\beta_{4}\right)\right]
$$

in case of taking historical changes into account, give us the respective inflation threshold that minimizes income inequality as measured by $G_{t}$. In contrast to the related study by Galli and van der Hoeven (2001), our specification strategy allows for changes in the slope and shape of the convex relationship between Gini coefficient and inflation rate through $D_{t}$.

The results of our estimates of model (3) are displayed in Table 1 below. It reports our findings for 1951-86, i.e. the period up to tax year 1986, as well as for the full sample period, i.e. from 1951 to 1991. From 1986 on tax bracket boundaries were indexed for inflation, using the US Department of Labor Consumer Price Index for Urban Consumers (CPS-U); see IRS (2003), p. 327. According to our estimates, the threshold values of inflation, marking the start of a regressive regime for inflation rates higher than these critical values, are calculated as $10.08 \%$ (18.01\%) for the 1951-86 subsample and $9.71 \%$ (29.71\%) for our full sample period, where figures taking tax bracket changes into account are given in parantheses. These figures are remarkably concordant with the findings of Galli and van der Hoeven (2001). These authors suggest on the base of their estimates that 'reducing inflation from moderate (around 12\%) to low (around 6\%) rates would decrease inequality in the US.' As can be seen from Figure 1 and 2 below, our results are indicative for a Ushaped relationship and a predominating (though rather negligible in quantitative terms) cold progression-regime in a historically plausible range of values of the inflation rate. ${ }^{7}$ We find this predominance regardless of taking historical changes in income tax boundaries into account or not. However, although our findings remain qualitatively the same in case of employing the business cycle components as extracted by HP-filtering or log first differences of the series in our regressions, ${ }^{8}$ they are sensitive with regard to the following: (a) The chosen definition of our changes-in-tax-system dummy $D_{t}$ and (b) the specification of the trend function $f(t)$ in case of estimating in levels. We obtain the reported significant results only by choosing for (a) $T B B_{t}$ (for detail see appendix) and a polynomial trend

\footnotetext{
${ }^{6}$ I.e. for $D_{t}=0$ for all $t=1, \ldots, T$.

${ }^{7}$ For our sample's range, it is only the three-years period 1979-81, where the US inflation rate exceeds values of $10 \%$.

${ }^{8}$ All time series and estimates are available on request from the authors.
} 
function for (b). It should be noted that this sensitivity of results based on our BES-type estimates seems not to be due to a structural break in the relationship for the oil price shocks period or the post-1983 period, as suggested in Galli and van der Hoeven (2001). We find no significant evidence for such a structural break in our regressions.

BES-type estimates have often been criticized to exclusively capture cyclical elements of the impact of inflation on income distribution. However, in the limiting case where all variability of the income distribution could be ascribed to changes in inflation, unemployment, and some secular trend, one may sum the short-term effects to gauge the total long-run impact of inflation on income distribution ceteris paribus. This would correspond to the combined effect of the responsiveness of the economy (estimated coefficient) and the actual inflation outcomes; see Bulir and Gulde (1995). Thus, the long-term cumulative impact of inflation may simply be computed as

$$
\beta_{1} \sum_{t=1}^{T} \pi_{t}+\beta_{3} \sum_{t=1}^{T} \pi_{t}^{2}
$$

for an upper benchmark value of cold progression, resultant for the case without any income tax adjustments, and as

$$
\left(\beta_{1}+\beta_{2}\right) \sum_{t=1}^{T} \pi_{t}+\left(\beta_{3}+\beta_{4}\right) \sum_{t=1}^{T} \pi_{t}^{2}
$$

to assess the effects of cold progression in the presence of tax bracket adjustments with a frequency as witnessed by the post-WW II US economy. The resulting cumulative effects for specification (4) are reported in Table 2 below. 
Table 1. Estimates of BES-type model; dependent variable: $G_{t}$

$$
G_{t}=\beta_{0}+\left(\beta_{1}+\beta_{2} D_{t}\right) \pi_{t}+\left(\beta_{3}+\beta_{4} D_{t}\right) \pi_{t}^{2}+\beta_{5} u_{t}+\beta_{6} t+\beta_{7} t^{2}+\varepsilon_{t},
$$

Est. coeff. Sub-sample: 1951-86 Full sample: 1951-91

\begin{tabular}{ccc}
\hline$\beta_{0}$ & $35.356^{* * *}$ & $35.327^{* * *}$ \\
& $(0.318)$ & $(0.261)$ \\
$\beta_{1}$ & $-0.269^{* * *}$ & $-0.274^{* * *}$ \\
& $(0.077)$ & $(0.076)$ \\
$\beta_{2}$ & $0.110^{*}$ & $0.143^{* *}$ \\
& $(0.056)$ & $(0.066)$ \\
$\beta_{3}$ & $0.013^{* *}$ & $0.014^{* * *}$ \\
& $(0.004)$ & $(0.004)$ \\
$\beta_{4}$ & -0.008 & $-0.011^{*}$ \\
& $(0.005)$ & $(0.006)$ \\
$\beta_{5}$ & 0.080 & 0.073 \\
& $(0.064)$ & $(0.048)$ \\
$\beta_{6}$ & $-0.141^{* * *}$ & $-0.130^{* * *}$ \\
& $(0.031)$ & $(0.031)$ \\
D-stat. & $0.005^{* * *}$ & $0.005^{* * *}$ \\
\hline Adj. R & $(0.001)$ & $(0.001)$ \\
\hline
\end{tabular}

Note: ${ }^{*},{ }^{* *},{ }^{* *} \equiv$ significance at $10,5,1 \%$ level of significance;

Newey-West HAC standard errors given in parentheses. 
Figure 1: Convex relationship of inflation rate and Gini coefficient I

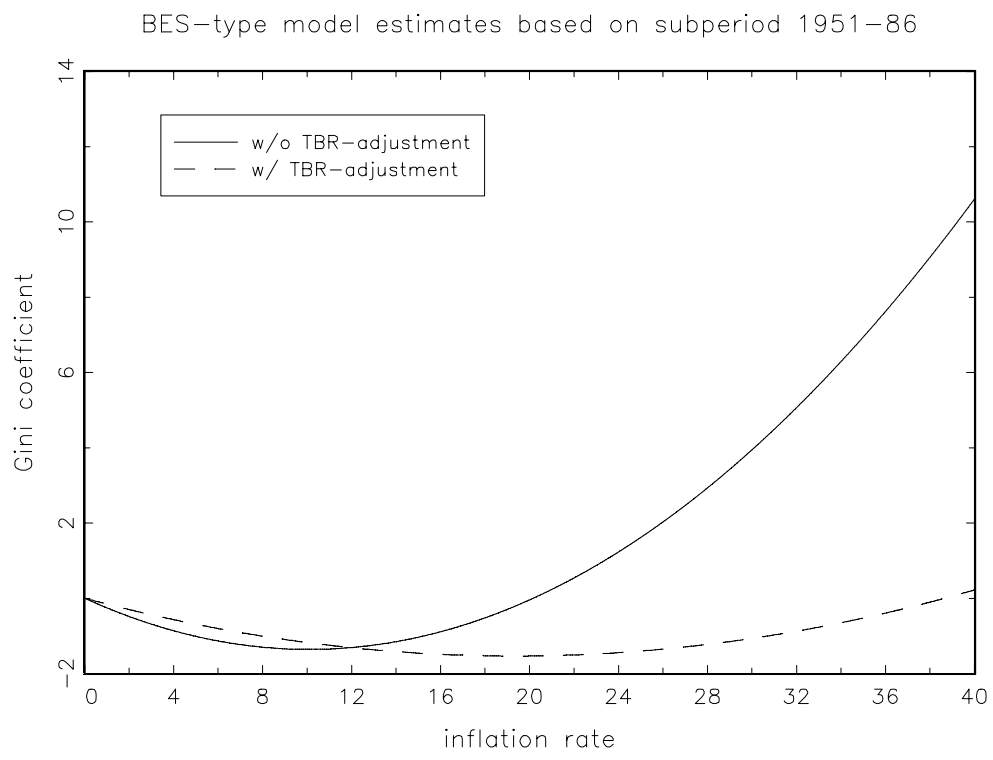

Figure 2: Convex relationship of inflation rate and Gini coefficient II

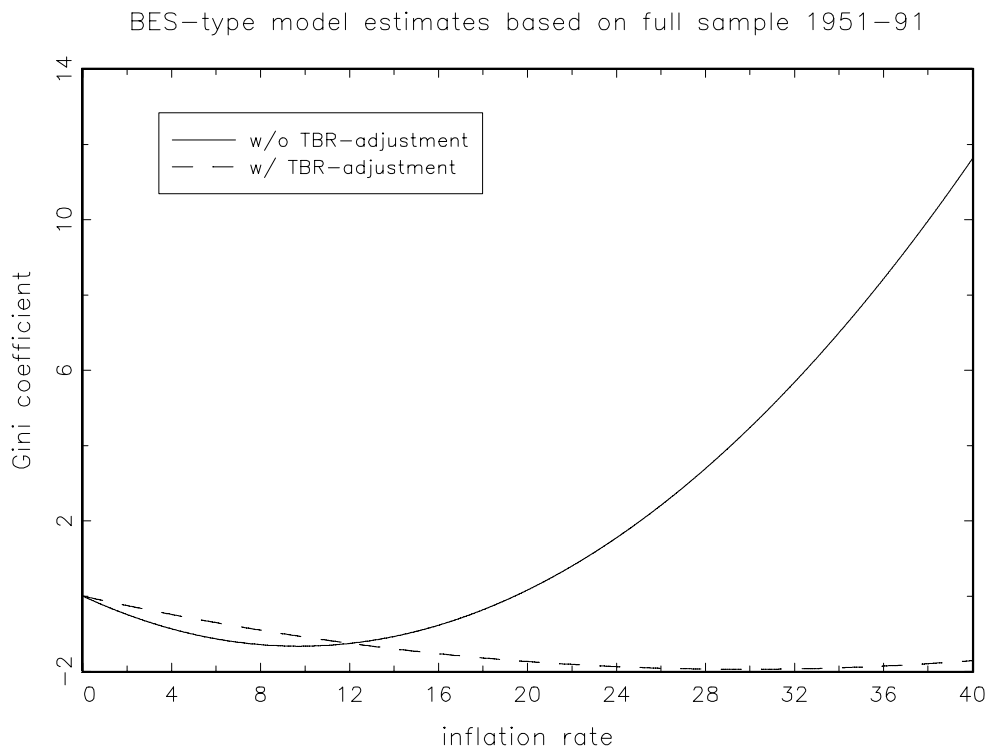


Table 2. Cumulative changes in percentage income shares (BES-type estimates)

\begin{tabular}{lllll} 
period & dependent & $\begin{array}{l}\text { inflation rate } \\
\text { w/o TBR-adj. }\end{array}$ & $\begin{array}{l}\text { inflation rate } \\
\text { w/ TBR-adj. }\end{array}$ \\
\hline \multirow{4}{*}{$1951-86$} & $Q_{1}$ & $+0.124^{* * *}$ & +0.092 & $-0.153^{* *}$ \\
& $Q_{2}$ & $+0.069^{* * *}$ & +0.056 & $-0.104^{* * *}$ \\
& $Q_{3}$ & +0.022 & +0.020 & +0.022 \\
& $Q_{4}$ & -0.002 & -0.032 & $+0.197^{* *}$ \\
& $Q_{5}$ & -0.213 & -0.136 & -0.017 \\
\hline \multirow{2}{*}{$1951-91$} & $Q_{1}$ & $+0.146^{* * *}$ & +0.102 & $-0.112^{* *}$ \\
& $Q_{2}$ & $+0.082^{* * *}$ & +0.057 & $-0.118^{* * *}$ \\
& $Q_{3}$ & +0.023 & +0.015 & +0.029 \\
& $Q_{4}$ & -0.004 & -0.043 & $+0.258^{* * *}$ \\
& $Q_{5}$ & -0.247 & -0.132 & -0.056 \\
\hline
\end{tabular}

Note: ${ }^{*},{ }^{* *},{ }^{* *}$ based on coefficients estimates significant at $10,5,1 \%$ level.

In summary, the above results based on BES-type regressions are indicative for the fact that inflation impacts on income distribution like a progressive income tax in a range of rates up to about $10 \%$ of inflation. In other words, they suggest a trade-off between the inflation rate and the Gini coefficient of households' incomes. However, this trade-off is close to negligible in quantitative terms. The computed cumulative effects of inflation on the US income distribution's quintile income shares is indicative for the following interpretation: The two lowest quintiles are significant relative long-term "winners" of inflation. Although, in the long run the second quintile is loosing significantly more in share through higher unemployment rates than winning through inflation. As can be seen from Table 1 above, however, the contemporaneous unemployment rate shows no significant explanatory power in case of investigating the overall Gini coefficient as dependent variable. Tax bracket adjustments that took place during our observation period seem to predominantly lower the effects of inflation on the income shares of the highest quintile, to disadvantage primarily the first ("inflation-winners") and the fourth ("inflation-loosers"), and to impact only marginally on the other quintiles' income shares. However, it should be noted that the latter finding is speculative, insofar as it is not statistically significant. 


\subsection{Basic error correction model (ECM) estimates}

At first glance, Figure 3 below is suggestive for a stationary deviation from long term equilibrium, i.e. a cointegrating relationship, between the US income distribution's Gini coefficient and the US inflation rate. Allowing for an integrated modelling of trend and autoregressive dynamics, we aim to test this hypothesis in the following with and without considering historical tax bracket boundaries adjustments $\left(T B B_{t}\right)$ as introduced in the preceding paragraphs and documented in the appendix.

As is common practice in cointegration analysis, we estimate our ECM specifications in natural logs. Therefore, we need to scale our inflation rate variable to $\widetilde{\pi}_{t}=1+\pi_{t}$ due to a negative value of the US inflation rate (deflation) in 1955, i.e. $\pi_{1955}=-0.49 \%$.

In detail, we consider the following univariate ECM specifications

$$
\begin{aligned}
\Delta \ln G_{t}= & \beta_{0}+\beta_{1} \Delta \ln \tilde{\pi}_{t}+\beta_{2} \Delta \ln \tilde{\pi}_{t}^{2}+\beta_{3} \Delta \ln u_{t}+\sum_{i=4}^{6} \beta_{i}\left(\ln G_{t-1}-\gamma_{z} \ln z_{t-1}\right)+\varepsilon_{t},(5) \\
\Delta \ln G_{t}= & \beta_{0}+\left(\beta_{1}+\beta_{2} T B B_{t}\right) \Delta \ln \tilde{\pi}_{t}+\left(\beta_{3}+\beta_{4} T B B_{t}\right) \Delta \ln \widetilde{\pi}_{t}^{2} \\
& +\beta_{5} \Delta \ln u_{t}+\sum_{i=6}^{8} \beta_{i}\left(\ln G_{t-1}-\gamma_{z} \ln z_{t-1}\right)+\varepsilon_{t}
\end{aligned}
$$

where $\varepsilon_{t}$ is an i.i.d. normal error and the summation term represents the respective cointegrating or error correction equations. $\Delta$ denotes first differences and $z=\left\{\tilde{\pi}, \tilde{\pi}^{2}, u\right\}$. The $\gamma_{z}$-values are taken from the respective long term multiplier relationship estimated by general dynamic models of the form

$$
\ln G_{t}=\alpha_{0}+\alpha_{1} \ln G_{t-1}+\rho_{0} \ln z_{t}+\rho_{1} \ln z_{t-1}+\varepsilon_{t}
$$

for $z=\left\{\tilde{\pi}, \tilde{\pi}^{2}, u\right\}$. Thereof, $\gamma_{z}$ is calculated as $\gamma_{z}=\left(\rho_{0}+\rho_{1}\right) /\left(1-\alpha_{1}\right)$. This procedure is well known as the Engle-Granger two-step estimator for models involving cointegrated variabels; see Banerjee et al. (1993), p. 157-161.

As can be seen from Table 3 below, we find a significant stationary, or I(0), combination of $G_{t}$ and $\tilde{\pi}_{t}$, i.e. a significant cointegrating equation, only in case of specification ECM1. All other specifications show no significant long-run relationship between $G_{t}$ and $\widetilde{\pi}_{t}$ or $\tilde{\pi}_{t}^{2}$. 
Table 3. Basic ECM estimates; full sample: 1951-1991

\begin{tabular}{|c|c|c|c|}
\hline Specification: & ECM1 & ECM2 & ECM3 \\
\hline$\Delta \ln \tilde{\pi}_{t}$ & -0.005 & $+0.026^{* *}$ & $+0.020^{*}$ \\
\hline $\ln G_{t-1}-\gamma_{\tilde{\pi}} \ln \tilde{\pi}_{t-1}$ & $+0.023^{* *}$ & +0.114 & +0.072 \\
\hline$\Delta \ln \tilde{\pi}_{t}^{2}$ & & $-0.014^{* * *}$ & $-0.011^{* *}$ \\
\hline $\ln G_{t-1}-\gamma_{\tilde{\pi}^{2}} \ln \tilde{\pi}_{t-1}^{2}$ & & -0.074 & -0.052 \\
\hline$\Delta \ln u_{t}$ & & & $+0.028^{* * *}$ \\
\hline $\ln G_{t-1}-\gamma_{u} \ln u_{t-1}$ & & & $+0.017^{* * *}$ \\
\hline Adj. $R^{2}$ & 0.153 & 0.300 & 0.433 \\
\hline F-Stat. & 4.540 & 5.184 & 5.977 \\
\hline$\Delta \ln \tilde{\pi}_{t}$ & -0.005 & $+0.026^{* *}$ & $+0.017^{*}$ \\
\hline$T B B_{t} \Delta \ln \tilde{\pi}_{t}$ & -0.002 & $-0.088^{*}$ & -0.032 \\
\hline $\ln G_{t-1}-\gamma_{\widetilde{\pi}} \ln \widetilde{\pi}_{t-1}$ & $+0.023^{* *}$ & +0.112 & +0.051 \\
\hline$\Delta \ln \tilde{\pi}_{t}^{2}$ & & $-0.014^{* * *}$ & $-0.011^{* *}$ \\
\hline$T B B_{t} \Delta \ln \tilde{\pi}_{t}^{2}$ & & $+0.035^{*}$ & +0.017 \\
\hline $\ln G_{t-1}-\gamma_{\tilde{\pi}^{2}} \ln \tilde{\pi}_{t-1}^{2}$ & & -0.072 & -0.036 \\
\hline$\Delta \ln u_{t}$ & & & $+0.030^{* *}$ \\
\hline $\ln G_{t-1}-\gamma_{u} \ln u_{t-1}$ & & & $+0.019^{* * *}$ \\
\hline Adj. $R^{2}$ & 0.131 & 0.275 & 0.426 \\
\hline F-Stat. & 2.972 & 3.471 & 4.619 \\
\hline
\end{tabular}

Note: ${ }^{*},{ }^{* *},{ }^{* *}$ denotes significant at $10,5,1 \%$ level (based on Newey-West HAC standard errors).

\subsection{Vector error correction model (VECM) estimates}

Although, we found no clear evidence of cointegration between the nonstationary $G_{t^{-}}$and $\widetilde{\pi}_{t}$-series from our basic ECM estimates, we proceed to model them in a restricted VAR framework that has cointegrating restrictions built into the specification, i.e. in a VECM framework. This subsection therefore has two primary objectives: First, to give our empirical models a more vigorous dynamic structure and second, to investigate the empirical impulse responses calculated on the base of our VECM estimates. 
Figure 3: US inflation rate and Gini coefficient: 1951-91

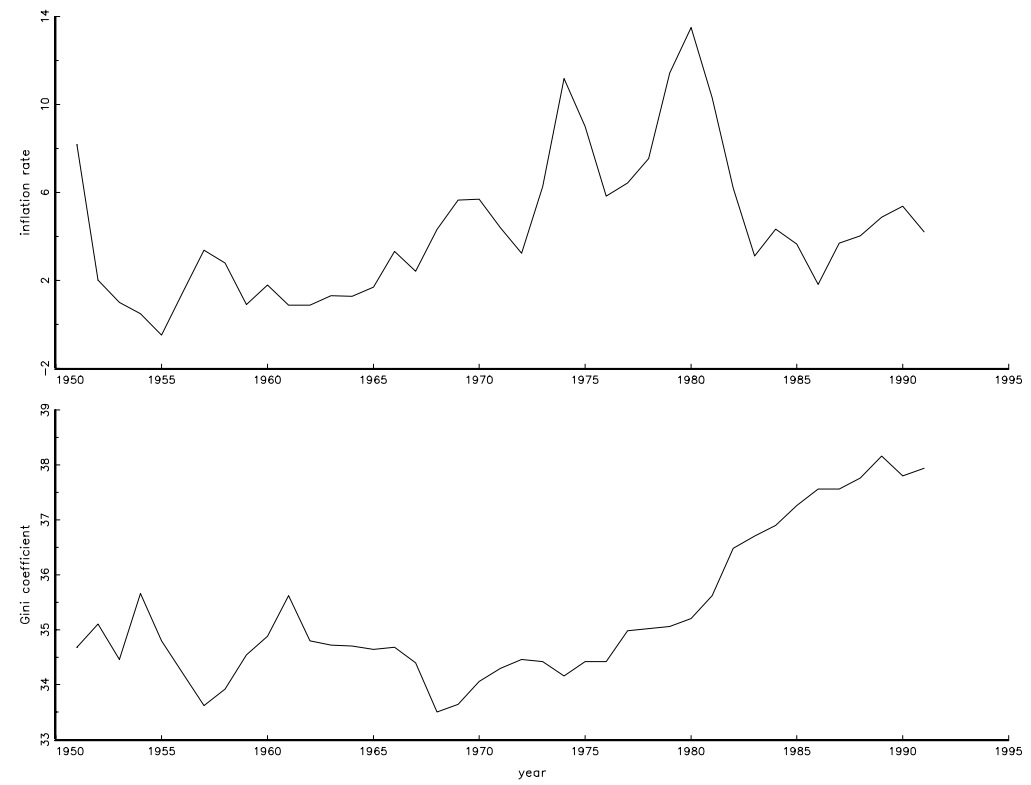

Consider a VAR of order $p$ :

$$
\mathbf{y}_{t}=\mathbf{A}_{1} \mathbf{y}_{t-1}+\ldots+\mathbf{A}_{p} \mathbf{y}_{t-p}+\mathbf{B} \mathbf{x}_{t}+\varepsilon_{t}
$$

where, in our case, $\mathbf{y}_{t}$ is a $2 \times 1$-vector of nonstationary $\mathrm{I}(1)$ variables, i.e. $\left(\ln G_{t} \ln \widetilde{\pi}_{t}\right)^{\prime}, \mathbf{x}_{t}$ is a $4 \times 1$-vector of deterministic variables, as given here by $\left(\ln \tilde{\pi}_{t} \ln \widetilde{\pi}_{t}^{2} \ln u_{t} \ln u_{t}^{2}\right)^{\prime}$, and $\varepsilon_{t}$ denotes a vector of innovations. We can rewrite this VAR as:

$$
\Delta \mathbf{y}_{t}=\mathbf{\Pi} \mathbf{y}_{\mathbf{t}}+\sum_{i=1}^{p-1} \boldsymbol{\Gamma}_{i} \Delta \mathbf{y}_{t-i}+\mathbf{B} \mathbf{x}_{t}+\varepsilon_{t}
$$

where

$$
\boldsymbol{\Pi}=\sum_{i=1}^{p} \mathbf{A}_{i}-I, \boldsymbol{\Gamma}_{i}=-\sum_{j=i+1}^{p} \mathbf{A}_{j} .
$$

For our particular variables of interest, the deterministic part of the corresponding unrestricted VAR of order 2 can be written as

$$
\begin{aligned}
\left(\begin{array}{c}
\Delta \ln y_{t} \\
\Delta \ln \tilde{\pi}_{t}
\end{array}\right)= & \left(\begin{array}{c}
\alpha_{0} \\
\alpha_{1}
\end{array}\right)\left(\begin{array}{lll}
\beta_{0} & \beta_{1} & \beta_{2}
\end{array}\right)\left(\begin{array}{c}
1 \\
\ln y_{t-1} \\
\ln \widetilde{\pi}_{t-1}
\end{array}\right)+ \\
& \left(\begin{array}{ccc}
\beta_{1,3} & \ldots & \beta_{1,7} \\
\beta_{2,3} & \ldots & \beta_{2,7}
\end{array}\right)\left(\begin{array}{llll}
1 & \Delta \ln y_{t-1} & \Delta \ln \widetilde{\pi}_{t-1} & \ln z_{t}
\end{array}\right)^{\prime},
\end{aligned}
$$


for $y_{t}=\left\{G_{t}, Q_{1, t}, Q_{5, t}\right\}, y_{t-1}=\left\{G_{t-1}, Q_{1, t-1}, Q_{5, t-1}\right\}$, and $z_{t}=\left\{\widetilde{\pi}_{t}, \widetilde{\pi}_{t}^{2}, u_{t}, u_{t}^{2}\right\}$. Obviously, we concentrate on the lowest and highest income quintile and, by considering $u_{t}^{2} \in z_{t}$, allow for a sort of Phillips Curve relationship in the second equation of the specified system.

It can be shown that if the coefficient matrix $\Pi$ has reduced rank $r<k=2$, then there exist two $k \times r$-matrices $\alpha$ and $\beta$ each with rank $r$ such that $\Pi=\alpha \beta^{\prime}$ and $\beta^{\prime} \mathbf{y}_{t}$ is stationary. The number of cointegrating relations, or cointegrating rank, is given by $r$, while $\beta$ represents the cointegrating vector. The popular Johansen-Cointegration-test then consists in estimating matrix $\Pi$ in its unrestricted form and proceedingly in testing whether the restrictions implied by the reduced rank of $\Pi$ can be rejected.

In contrast to specification

$$
\begin{aligned}
\left(\begin{array}{c}
\Delta \ln y_{t} \\
\Delta \ln \tilde{\pi}_{t}
\end{array}\right)= & \left(\begin{array}{l}
\alpha_{0} \\
\alpha_{1}
\end{array}\right)\left(\begin{array}{lll}
\beta_{0} & \beta_{1} & \beta_{2}
\end{array}\right)\left(\begin{array}{c}
1 \\
\ln y_{t-1} \\
\ln \widetilde{\pi}_{t-1}
\end{array}\right)+ \\
& \left(\begin{array}{ccc}
\beta_{1,3} & \ldots & \beta_{1,9} \\
\beta_{2,3} & \ldots & \beta_{2,9}
\end{array}\right)\left(\begin{array}{llll}
1 & \Delta \ln y_{t-1} & \Delta \ln \tilde{\pi}_{t-1} & \ln z_{t}
\end{array}\right)^{\prime},
\end{aligned}
$$

for $y_{t}$ and $y_{t-1}$ as given above and $z_{t}=\left\{\widetilde{\pi}_{t}, \widetilde{\pi}_{t}^{2}, T B B_{t} \widetilde{\pi}_{t}, T B B_{t} \widetilde{\pi}_{t}^{2}, u_{t}, u_{t}^{2}\right\}$, i.e. the case of taking historical tax bracket boundaries adjustments into account, for specification (8) the L.R.-test as part of the Johansen-Test procedure rejects the hypothesis of no cointegration but not the hypothesis of at most one cointegrating relation. For (9) both hypotheses are rejected at the five percentage level of significance. Detailed results can be given in an extended appendix which is available and will be furnished on request.

Figures 4 and 5 below display the implied impulse responses (IRs) for the full sample (1951-91) and sub-sample (1951-86) period of estimations (8) and (9), respectively. Since none of our specifications generates statistically significant coefficient estimates for the inflation variables, we abstract from calculating bootstrapped or similar asymptotic confidence bands. Surprisingly, the qualitative result, i.e. the shape of the implied IR-functions is obviously not in line with our previous findings: After about three to four periods of adjustment a one percentage standard deviation shock on the inflation rate leads to a permanent increase (decrease) of the Gini coefficient and the highest quintile's income share (of the lowest quintile's income share). Apart from a somehow smoother adjustment of the Gini to the inflationary shock, taking historical tax bracket adjustments into account does not change the results qualitatively. Again, quantitatively it also implies negligible effects. 
Figure 4: Impulse responses for VECM-specification: equation (8)

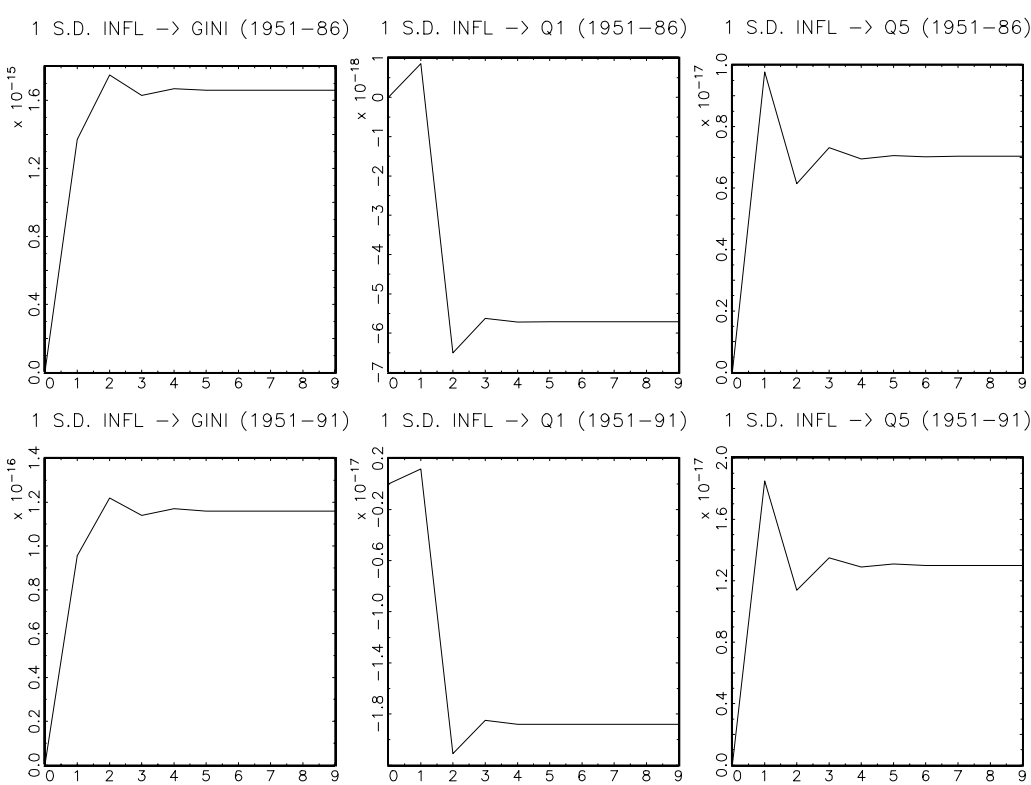

Figure 5: Impulse responses for VECM-specification: equation (9)
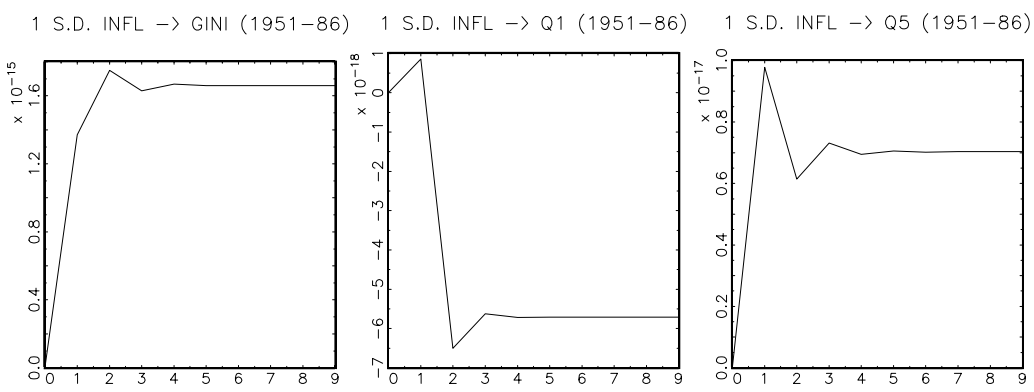

1 S.D. INFL $\rightarrow$ GINI $(1951-91)$

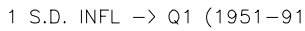

1 S.D. INFL $\rightarrow$ Q5 (1951-91)
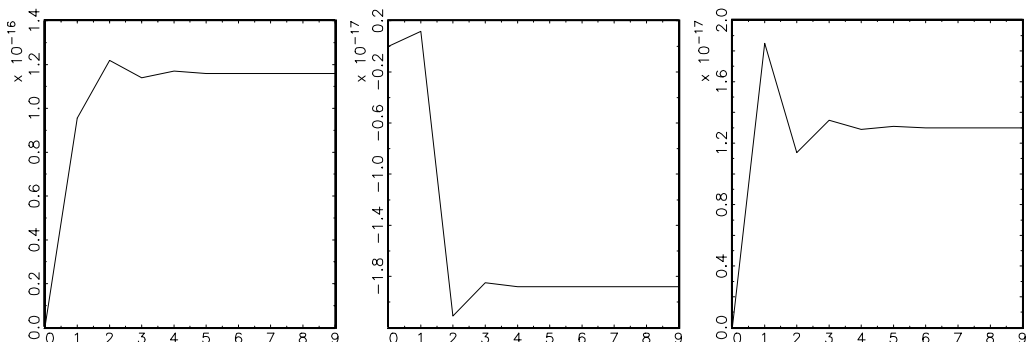
In summary, our empirical analysis lends support to the view that inflation reduces the inequality of the income distribution for the post-WW II US economy. Although, this trade-off is close to negligible in quantitative terms, it holds in case of considering historical tax bracket boundaries adjustments. Though not a statistically robust result, it seems that it was only the richest quintile profiting from these adjustments in terms of income share in the four decades at stake; cf. Table 2 above. Evidence on the long-run relationship between inflation and the considered measures of the US income distribution is notably mixed and mostly statistically insignificant. This, especially, holds for our (V)ECM estimates: Neither our ECM nor our VECM specifications produce statistically robust coefficient estimates for the inflation variables. Therefore, both reported results need to be interpreted with adequate caution.

\section{A monetary general equilibrium model with pro- gressive income taxation}

In this section, we develop a general equilibrium overlapping generations model with endogenous equity and money distribution. Four sectors can be depicted: households, production, the government, and the central bank. Household maximize discounted life-time utility. Agents can save either with money or with capital. Individuals are heterogeneous with regard to their productivity and cannot insure against idiosyncratic income risk. Firms maximize profits. Output is produced with the help of labor and capital. The government provides unfunded public pensions which are financed by a progressive tax on wage and capital income. The money growth rate is set by the central bank and seignorage is redistributed lump-sum to the households.

\subsection{Households}

Every year, a generation of equal measure is born. A subscript $j$ of a variable denotes the age of the generation. The total measure of all households is normalized to one.

Households life a maximum of $T+T^{R}$ years. Lifetime is stochastic and agents face a probability $s_{j}$ of surviving up to age $j$ conditional on surviving up to age $j-1$. During 
their first $T$ years, agents supply labor $l$ elastically. After $T$ years, retirement is mandatory. Agent $i$ maximizes her life-time utility:

$$
E_{0}\left[\sum_{j=1}^{T+T^{R}} \beta^{j-1}\left(\Pi_{h=1}^{j} s_{h}\right) u\left(c_{j}^{i}, m_{j}^{i}, 1-l_{j}^{i}\right),\right]
$$

where $\beta, c_{j}^{i}$, and $m_{j}^{i}$ denote the discount factor, consumption and real money balances of agent $i$ at age $j$, respectively. Instantaneous utility $u(c, m, 1-l)$ is given by:

$$
u(c, m, 1-l)=\ln c+(1-\gamma) \ln m+B \ln (1-l) .
$$

Workers are heterogeneous with regard to their labor earnings per working hour. The worker's labor productivity $e(z, j)$ is stochastic and depends on his age $j$ and an idiosyncratic labor productivity shock $z$. We assume that the idiosyncratic part of productivity follows a first order finite state Markov chain with conditional transition probabilities given by:

$$
\pi\left(z^{\prime} \mid z\right)=\operatorname{Pr}\left\{z_{t+1}=z^{\prime} \mid z_{t}=z\right\}
$$

where $z, z^{\prime} \in \mathcal{E}$. Although the dynamics of productivity may be modelled slightly better by a second order Markov chain (Shorrocks, 1976) the improvement in accuracy is rather small and does not justify the considerable increase in the model's complexity.

Furthermore, agents are born without wealth, $a_{1}=0$, and cannot borrow, $a_{j} \geq 0$ for all $j$. Wealth $a$ is composed of real money $m$ and capital $k$. Capital or, equally, equity $k$ earns a real interest rate $r$. We further assume a short-sale constraint $k \geq 0$. Parents do not leave altruistic bequests to their children. All accidental bequests are confiscated by the state. Agent $i$ receives income from capital $k^{i}$ and labor $l^{i}$. The budget constraint of the working agent at age $j=1, \ldots, T$ in period $t$ is given by

$$
a_{j+1, t+1}^{i}=k_{j+1, t+1}^{i}+m_{j+1, t+1}^{i}=\left(1+r_{t}\right) k_{j t}^{i}+\frac{m_{j t}^{i}}{1+\pi_{t}}+w_{t} e(z, j) l_{j t}^{i}+t r_{t}-\frac{\tau_{t}\left(P_{t} y_{j t}^{i}\right)}{P_{t}}+c_{j t}^{i}
$$

where $w_{t}$ and $\pi_{t}=\frac{P_{t}-P_{t-1}}{P_{t-1}}$ denote the wage rate per efficiency unit labor and the inflation rate in period $t$, respectively. $P_{t}$ is the price level in period $t$. Individual nominal 
income $P_{t} y_{j t}^{i} \equiv P_{t} w_{t} e(z, j) l_{j t}^{i}+P_{t} r_{t} k_{j t}^{i}$ is taxed at the progressive rate $\tau .{ }^{9}$ In addition, the households receive transfers $t r_{t}$ from the central bank.

During retirement, agents receive public pensions pen $_{t}$ in period $t$ irrespective of their employment history and the budget constraint of the retired agent at age $j=T+1, \ldots, T+$ $T^{R}$ is given by

$$
a_{j+1, t+1}^{i}=k_{j+1, t+1}^{i}+m_{j+1, t+1}^{i}=\left(1+r_{t}\right) k_{j t}^{i}+\frac{m_{j t}^{i}}{1+\pi_{t}}+p e n_{t}+t r_{t}-\frac{\tau_{t}\left(P_{t} y_{j t}^{i}\right)}{P_{t}}-c_{j t}^{i} .
$$

The necessary conditions of the households with regard to consumption $c_{j t}^{i}$, capital $k_{j+1, t+1}^{i}$, real money $m_{j+1, t+1}^{i}$, and labor $l_{j t}^{i}$ are as follows:

$$
\begin{aligned}
u_{c}\left(c_{j t}^{i}, m_{j t}^{i}, 1-l_{j t}^{i}\right) & =\lambda_{j t}^{i} \\
\lambda_{j t}^{i} & =\beta E_{t}\left[\lambda_{j+1, t+1}^{i}\left(1+r_{t+1}\left(1-\frac{\partial \tau}{\partial P_{t+1} y_{j+1, t+1}^{i}}\right)\right)\right] \\
\lambda_{j t}^{i} & =\beta E_{t}\left[\lambda_{j+1, t+1}^{i} \frac{1}{1+\pi_{t+1}}+u_{m}\left(c_{j+1, t+1}^{i}, m_{j+1, t+1}^{i}, 1-l_{j+1, t+1}^{i}\right)\right] \\
u_{l}\left(c_{j t}^{i}, m_{j t}^{i}, 1-l_{j t}^{i}\right) & =\lambda_{j t}^{i} w_{t} e(j, z)\left[1-\frac{\partial \tau}{\partial P_{t} y_{j t}^{i}}\right],
\end{aligned}
$$

where $u_{x}($.$) denotes the first partial derivative of the utility function with regard to the$ argument $x=c, 1-l, m$.

\subsection{Production}

Firms are of measure one and produce output with effective labor $N$ and capital $K$. Effective labor $N_{t}$ is the product of working hours and individual productivity and is defined in more detail below.

Effective labor $N_{t}$ is paid the wage $w_{t}$. Capital $K_{t}$ is hired at rate $r_{t}$ and depreciates at rate $\delta$. Production $Y_{t}$ is characterized by constant returns to scale and assumed to be Cobb-Douglas:

$$
Y_{t}=F\left(K_{t}, N_{t}\right)=K_{t}^{\alpha} N_{t}^{1-\alpha} .
$$

\footnotetext{
${ }^{9}$ In models similar to ours (but without a monetary sector), Ventura (1999) and Castañeda et al. (1999) study the effects of a flat rate tax reform on distribution and welfare. We follow Castañeda et al. who assume that both labor and interest income are taxed at the same rate.
} 
In a factor market equilibrium, factors are rewarded with their marginal product:

$$
\begin{aligned}
w_{t} & =(1-\alpha) K_{t}^{\alpha} N_{t}^{-\alpha}, \\
r_{t} & =\alpha K_{t}^{\alpha-1} N_{t}^{1-\alpha}-\delta .
\end{aligned}
$$

\subsection{Government}

Government expenditures consists of government consumption $G_{t}$, government lump-sum transfers $\operatorname{Tr}_{t}$ to households, and social securities expenditures $P e n_{t}$. Government expenditures are financed by an income tax $T_{a x}$ and confiscated accidental bequests $B e q_{t}$ :

$$
G_{t}+P e n_{t}+\operatorname{Tr}_{t}=\operatorname{Tax}_{t}+B e q_{t} .
$$

We follow Castanñeda et al. (1999) and characterize the US income tax structure by a progressive tax function. In particular, we also adapt the following functional form for the income tax function that is based upon the estimates of Gouveira and Strauss (1994):

$$
\tau\left(P_{t} y_{t}\right)=b_{0, t}\left(y-\left(y^{-b_{1, t}}+b_{2, t}\right)^{-\frac{1}{b_{1, t}}}\right)
$$

We further assume that the government adjusts the nominal income tax brackets every $T B$ year. Without the loss of generality, we assume that the income tax rate schedule is adjusted in periods (=years) $t \in\{0, T B, 2 T B, 3 T B, \ldots\}$. With regard to our tax function (23), this is equivalent to assume that the tax parameters $\left\{b_{0, t}, b_{1, t}, b_{2, t}\right\}$ are adjusted every $T B$ years so that the real tax burden is the same as in the benchmark year $t=0$. As a consequence, agents average and marginal income tax rates increases in the years between two successive tax rate adjustments as inflation increases the nominal income $P_{t} y_{j t}^{i}$ ceteris paribus.

\subsection{Monetary authority}

Nominal money grows at the exogenous rate $\theta$ :

$$
\frac{M_{t}-M_{t-1}}{M_{t-1}}=\theta .
$$


The seignorage is transferred lump-sum to the households:

$$
t r_{t}=\frac{M_{t}-M_{t-1}}{P_{t}}
$$

\subsection{Stationary equilibrium}

The concept of equilibrium applied in this paper uses a recursive representation of the consumer's problem following Stokey et al. (1989). Let $V_{j t}^{i}\left(k_{j t}^{i}, m_{j t}^{i}, z\right)$ be the value of the objective function of the $j$-year old agent with equity $k_{j t}^{i}$, real money $m_{j t}^{i}$, and idiosyncratic productivity level $z . V_{j t}^{i}\left(k_{j t}^{i}, m_{j t}^{i}, z\right)$ is defined as the solution to the dynamic program:

$$
\begin{aligned}
& V_{j t}^{i}\left(k_{j t}^{i}, m_{j t}^{i}, z\right)= \\
& \max _{k_{j+1, t+1}^{i}, m_{j+1, t+1}^{i}, c_{j t}^{i}, l_{j t}^{i}}\left\{u\left(c_{j t}^{i}, m_{j t}^{i}, 1-l_{j t}^{i}\right)+\beta s_{j+1} E_{t}\left[V_{j+1, t+1}^{i}\left(k_{j+1, t+1}^{i}, m_{j+1,+t 1}^{i}, z^{\prime}\right)\right]\right\}
\end{aligned}
$$

subject to (12), (13) or (14) and $k, m \geq 0$. Optimal decision rules of the agent $i$ in period $t$ at age $j$ are a function of the individual state variables $k_{j t}^{i}, m_{j t}^{i}$, and $z$, the distribution of capital and money, $\mu$, and the tax schedule. As the tax schedule is adjusted every $T B$ periods, the period $t$ is also an argument of the policy function. Let $c_{t}(k, m, z, j, \mu)$, $l_{t}(k, m, z, j, \mu), k_{t}^{\prime}(k, m, z, j, \mu)$, and $m_{t}^{\prime}(k, m, j, \mu)$ denote the optimal consumption, labor supply, next-period capital stock, and next-period real money balances for a $j$-year aged individual with productivity $z$, capital stock $k$, and real money balances $m$, and distribution of capital $k$ and money $m$ in period $t$. Furthermore, let $\mu_{t}(k, m, z, j)$ denote the measure of $j$-year old agents with productivity $z$ in period $t$ that hold capital $k$ and real money balances $m$.

We will consider a stationary equilibrium where the inflation rate is constant in every period $t$. Furthermore, government consumption is assumed to be constant, $G_{t}=G$, and pensions pen $_{t}$ are assumed to be of equal magnitude every $T B$ periods, respectively. As a consequence, the factor prices, aggregate capital and labor, and the distribution $\mu_{t}$ are also the same every $T B$ periods, respectively.

\section{Definition}

A stationary equilibrium for a given government policy $\left\{b_{0, t}, b_{1, t}, b_{2, t}, G_{t}\right.$, pen $\left._{t}\right\}$ and central 
bank policy $\theta_{t}=\theta$ is a collection of value functions $V_{j t}^{i}(k, m, z)$, individual policy rules $c_{t}(k, m, z, j, \mu), l_{t}(k, m, z, j, \mu), k_{t}^{\prime}(k, m, z, j, \mu), m_{t}^{\prime}(k, m, z, j, \mu)$, relative prices of labor and capital $\left\{w_{t}, r_{t}\right\}$, and a law of motion for the distribution $\mu_{t+1}=g\left(\mu_{t}\right)$ such that:

1. Money grows at the exogenous rate $\theta$ and the seignorage (25) is transferred lump-sum to the households.

2. The inflation rate $\pi_{t}$ is constant and equal to the money growth rate $\theta$.

3. The government adjusts the tax schedule in the years $\{0, T B, 2 T B, \ldots\}$. In the years $t \in\{p+T B, p+2 T B, p+3 T B, \ldots\}, p=0, \ldots, T B-1$, government consumption $G_{t}$ and individual pensions pen $_{t}$ are the same, respectively so that all exogenous variables in the economy are the same every $T B$ periods.

4. The government budget (22) is balanced.

5. Individual and aggregate behavior are consistent:

$$
\begin{aligned}
K_{t} & =\sum_{j=1}^{T+T^{R}} \int_{k} \int_{m} \int_{z} k \mu_{t}(k, m, z, j) d z d m d k \\
N_{t} & =\sum_{j=1}^{T} \int_{k} \int_{m} \int_{z} l_{t}(k, m, z, j, \mu) e(z, j) \mu_{t}(k, m, z, j) d z d m d k \\
C_{t} & =\sum_{j=1}^{T+T^{R}} \int_{k} \int_{m} \int_{z} c_{t}(k, m, z, j, \mu) \mu_{t}(k, m, z, j) d z d m d k \\
\operatorname{Pen}_{t} & =\sum_{j=T+1}^{T+T^{R}} \int_{k} \int_{m} \int_{z} p e n_{t} \mu_{t}(k, m, z, j) d z d m d k, \\
\operatorname{Tax}_{t} & =\sum_{j=T+1}^{T+T^{R}} \int_{k} \int_{m} \int_{z} \frac{\tau\left(P_{t} y_{t}(k, m, z, j)\right)}{P_{t}} \mu_{t}(k, m, z, j) d z d m d k \\
\operatorname{Beq}_{t} & =\sum_{j=1}^{T+T^{R}} \int_{k} \int_{m} \int_{z}\left(1-s_{j+1}\right) a_{t-1}^{\prime}(k, m, z, j, \mu) \mu_{t-1}(k, m, z, j) d z d m d k \\
\frac{M}{P} & =\sum_{j=1}^{T+T^{R}} \int_{k} \int_{m} \int_{z} m \mu_{t}(k, m, z, j) d z d m d k,
\end{aligned}
$$

where $a_{t}^{\prime}(.) \equiv k_{t}^{\prime}()+.m_{t}^{\prime}($.$) are the optimal next-period assets and y_{t}(k, m, z, j)$ denotes the real income of a $j$-year old agent with productivity $z$, capital $k$, and money $m$ in period $t$. Furthermore, $t r_{t}=T r_{t}$. 
6. Relative prices $\left\{w_{t}, r_{t}\right\}$ solve the firm's optimization problem by satisfying (20) and (21).

7. Given the government policy $\left\{b_{0, t}, b_{1, t}, b_{2, t}, G_{t}\right.$, pen $\left._{t}\right\}$ and the distribution $\mu_{t}$, the individual policy rules $c_{t}(),. k_{t+1}^{\prime}(),. m_{t+1}^{\prime}($.$) , and l_{t}($.$) solve the consumer's dynamic$ program (26).

8. The goods market clears in every period $t$ :

$$
K_{t}^{\alpha} N_{t}^{1-\alpha}=C_{t}+\delta K_{t}+K_{t+1}-K_{t}
$$

9. The dynamics of the distribution $\mu_{t+1}=g\left(\mu_{t}\right)$ are consistent with individual behavior:

$$
\begin{aligned}
& \mu_{t+1}\left(k^{\prime}, m^{\prime}, z^{\prime}, j+1\right)= \\
& \quad \int_{k} \int_{m} \int_{z} 1_{k^{\prime}=k_{t}^{\prime}(k, m, z, j, \mu)} \cdot 1_{m^{\prime}=m_{t}^{\prime}(k, m, z, j, \mu)} \cdot \operatorname{Pr}\left(z^{\prime} \mid z\right) \cdot \mu_{t}(k, m, z, j) d z d m d k,
\end{aligned}
$$

where $1_{k^{\prime}=k_{t}^{\prime}(.)}$ is an indicator function that takes the value one if $k^{\prime}=k_{t}^{\prime}($.$) and$ zero otherwise. $1_{m^{\prime}=m_{t}^{\prime}(.)}$ is defined in an analogous way. Furthermore, the new-born generation has zero wealth, $k=0$ and $m=0 .{ }^{10}$ Notice further that, in particular, $\mu_{t}=\mu_{t+T B}$ in a stationary equilibrium.

In the Appendix, we describe the computational algorithm that we use in order to compute an approximation to this equilibrium.

\section{Calibration}

Periods correspond to years. We assume that agents are born at real lifetime age 20 which corresponds to $j=1$. Agents work $T=40$ years corresponding to a real lifetime age of 60. They life a maximum life of 60 years $\left(T^{R}=20\right)$ so that agents do not become older than real lifetime age 80 . The sequence of conditional survival probabilities $\left\{s_{j}\right\}_{j=1}^{59}$ is set

\footnotetext{
${ }^{10}$ For computational purpose, agents of the first-year generation are endowed with small money balances so that the utility function does not take the value of infinity.
} 
equal to the Social Security Administration's survival probabilities for men aged 20-78 for the year $1994 .^{11}$ The survival probabilities decrease with age, and $s_{60}$ is set equal to zero. The calibration of the parameters $\alpha, \delta$, pen, and $\theta$ and the Markov process $e(z, j)$ is chosen in accordance with existing general equilibrium studies. Following Prescott (1986), the capital income share $\alpha$ is set equal to 0.36 . The annual rate of depreciation is set equal to $\delta=0.08$. Pensions are distributed lump-sum to the retired agents. The replacement ratio of pensions to net average earnings amounts to $50 \%$ in every period $t$. Hence, pensions are a function of the distribution $\mu_{t}$ and, hence, $K_{t}$ and $N_{t}$, and are the same every $T B$ periods. The income tax rate is adjusted every $T B=3$ years in accordance with the findings presented in section $2 .{ }^{12}$ The model parameters are presented in Table 4.

The tax function (23) is calibrated with the help of the estimates from Gouveira/Strauss. ${ }^{13}$ In particular, we set the income tax parameters in period $t=0$ (where we normalized the price level to one, $P_{0}=1$ ) equal to $b_{0}=0.258, b_{1}=0.768, b_{2}=0.031$. The income tax parameters $b_{0}$ and $b_{1}$ are taken from Gouveira/Strauss for the tax year 1989, while $b_{2}$ has been adjusted so that the tax rate of the average income in our model is equal to the tax rate of the average US income. Every $T B$ years, these parameters are adjusted so that the average and marginal tax rates of the real income are unchanged between period $T B$ and $p \cdot T B, p=1,2, \ldots$.

The labor endowment process is given by $e(z, j)=e^{z_{j}+\bar{y}_{j}}$, where $\bar{y}_{j}$ is the mean lognormal income of the $j$-year old. The mean efficiency index $\bar{y}_{j}$ of the $\mathrm{j}$-year-old worker is taken from Hansen (1993), and interpolated to in-between years. As a consequence, the model is able to replicate the cross-section age distribution of earnings of the US economy. Following İmrohoroğlu et al. (1998), we normalize the average efficiency index to one. The ageproductivity profile is hump-shaped and earnings peak at age 50 .

The idiosyncratic productivity shock $z_{j}$ follows a Markov process. The Markov process is given by:

$$
z_{j}=\rho z_{j-1}+\epsilon_{j}
$$

where $\epsilon_{j} \sim N\left(0, \sigma_{\epsilon}\right)$. Huggett (1996) uses $\rho=0.96$ and $\sigma_{\epsilon}=0.045$. Furthermore, we

\footnotetext{
${ }^{11}$ We thank Mark Huggett and Gustavo Ventura for providing us with the data.

${ }^{12}$ Our qualitative results are the same in the cases $T B=2$ and $T B=4$. The results for the case $T B=4$ are also presented in section 5 .

${ }^{13}$ These parameter values have also been applied by Castañeda et al (1999).
} 
Table 4: Calibration of parameter values for the US economy

Description

utility function

discount factor

production function

depreciation

money growth rate

pension replacement rate
Function

Parameter

$$
U=\gamma \ln c+(1-\gamma) \ln m+B \ln (1-l)
$$

$\gamma=0.974, B=1.72$

$\beta$

$\beta=0.969$

$\alpha=0.36$

$Y=K^{\alpha} N^{1-\alpha}$

$\delta$

$\delta=0.08$

$\theta=0.05$

0.50

periods between

tax schedule adjustments

$T B=3$

income tax function

$\tau(y)=b_{0}\left(y-\left(y^{-b_{1}}+b_{2}\right)^{-\frac{1}{b_{1}}}\right)$

$b_{0}=0.258, b_{1}=0.768$,

$b_{2}=0.031$

labor endowment process $z_{t}=\rho z_{t-1}+\epsilon_{t}, \epsilon_{t} \sim N\left(0, \sigma_{\epsilon}\right)$

$\ln e(z, 1) \sim N\left(\bar{y}_{1}, \sigma_{y_{1}}\right)$ $\rho=0.96, \sigma_{\epsilon}=0.045$ $\sigma_{y 1}=0.38$ 
follow Huggett and choose a lognormal distribution of earnings for the 20-year old with $\sigma_{y_{1}}=0.38$ and mean $\overline{y_{1}}$. As the $\log$ endowment of the initial generation of agents is normally distributed, the log efficiency of subsequent agents will continue to be normally distributed. This is a useful property of the earnings process, which has often be described as log normally in the literature.

The remaining three parameters $\beta, B$, and $\gamma$ from the utility function are chosen to match the following characteristics of the US economy as closely as possible: i) the capital-output ratio $K / Y$ amounts to 3.0 as found by Auerbach and Kotlikoff (1995), ii) the average labor supply of the working households amounts to approximately one third of available time, and iii) the average velocity of money $P Y / M$ is equal to the annual velocity of M1 during 1960-2001, which is equal to 5.18. Our calibration $\beta=0.969, B=1.72$, and $\gamma=0.974$ implies a capital-output ratio equal to 2.98 , an average labor supply $\bar{l}=0.326$, and an annual velocity of money equal to 5.12 .

\section{Results}

In this section, we study the effects of a change of the money growth rate $\theta$ or, equally, the inflation rate $\pi$ on the stationary distribution of income. Remember that, in our benchmark case, the inflation rate is equal to $5 \%$ and the tax schedule is adjusted every 3 years. The effect of the cold progression on the marginal and average tax rates is illustrated in Figures 6 and 7 (where the average real income of the economy is normalized to one). Obviously, the average income tax and the marginal tax rate hardly change after one or two years of cold progression. Hence, we would expect only small effects from the cold progression on the individual's savings and labor supply.

Table 5 summarizes our results for the benchmark case. The first column gives the number of periods that have been elapsed since the last tax schedule adjustment. The remaining columns present the aggregate capital stock $K_{t}$, average labor supply $l_{t}$, aggregate effective labor $N_{t}$, aggregate production $Y_{t}$, average real money balances $m_{t}$, government transfers $t r_{t}$, and total income taxes $\operatorname{Tax}_{t}$, and the Gini coefficients of the income distribution. Notice that the increase in the marginal and average income tax rates between two successive periods of the tax schedule adjustment results in an increase of total income taxes of 
Figure 6: Average income tax rate

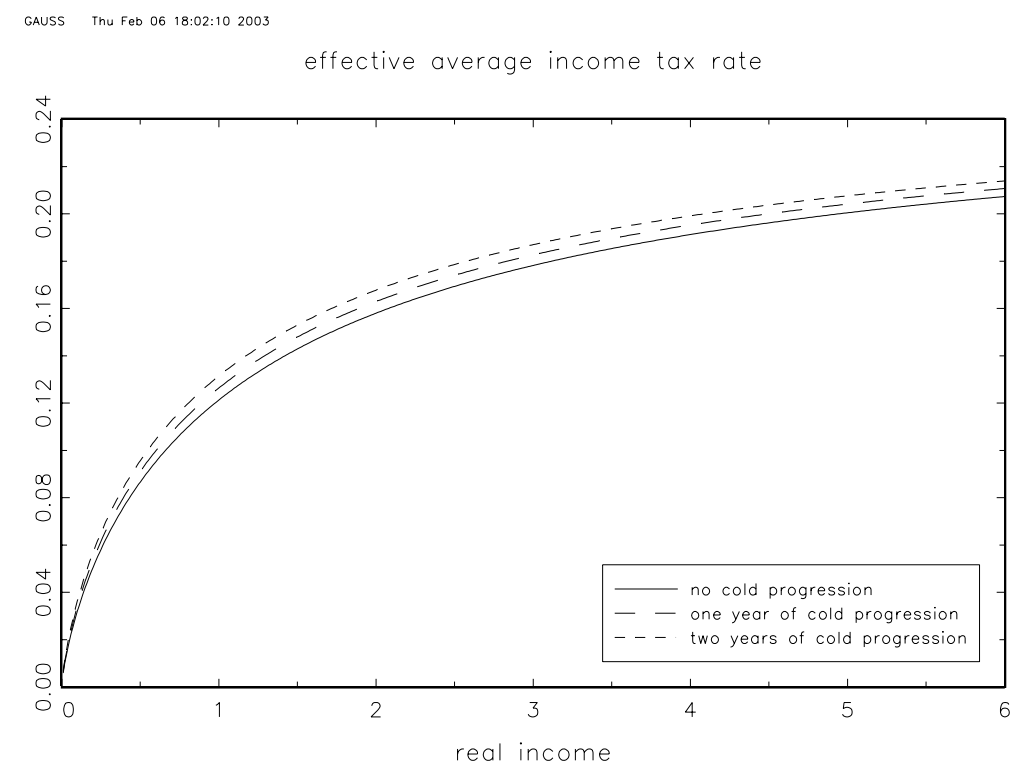

approximately $2.5 \%$ each year. Similarly, transfers to the households also increase in order to keep the government budget balanced. Surprisingly, aggregate savings, $K_{t}+\bar{m}_{t}$, and average labor supply $\bar{l}_{t}$ even increase with higher marginal tax rates. However, quantitative effects are of negligible order. As a consequence, the pre-tax wage income remains almost unchanged during the course of cold progression and is characterized by a Gini coefficient equal to approximately 0.56 . Notice that this value is close to values observed empirically. Díaz-Giménez et al. (1997) find a value of 0.51 for households aged 36-50. The Gini coefficient of the total net income is smaller and amounts to only 0.49 as income is taxed progressively and transfers are distributed lump-sum.

Our empirical analysis suggests that there exists an inflation rate in the range above $10 \%$ that minimizes the inequality in the income distribution. In order to consider the effects of a higher inflation rate, we recomputed the model for the money growth rate $\theta=\pi=10 \%$. The results for the high-inflation economy are summarized in Table 6 .

Following an increase of inflation from $5 \%$ to $10 \%$, agents reduce their stationary real money balances. The average real money balances $\bar{m}_{t}$ drops from 0.142 to 0.090 . Furthermore, 
Figure 7: Marginal income tax rate

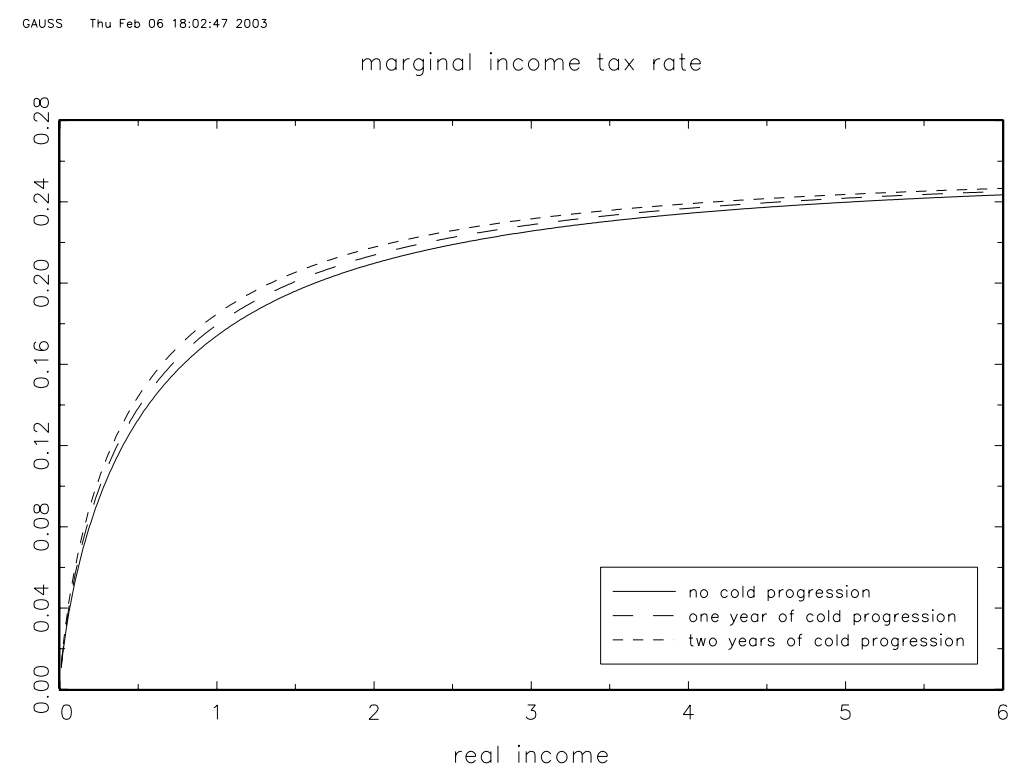

Table 5: Cold progression, aggregate values and distribution for $\pi=5 \%$

\begin{tabular}{|c|c|c|c|c|c|c|c|c|c|}
\hline \multirow{3}{*}{$\begin{array}{l}\text { year } t \text { after } \\
\text { tax code } \\
\text { adjustment }\end{array}$} & \multirow[b]{3}{*}{$K_{t}$} & \multirow[b]{3}{*}{$\bar{l}_{t}$} & \multirow[b]{3}{*}{$N_{t}$} & \multirow[b]{3}{*}{$Y_{t}$} & \multirow[b]{3}{*}{$\bar{m}_{t}$} & \multirow[b]{3}{*}{$t r_{t}$} & \multirow[b]{3}{*}{$\operatorname{Tax}_{t}$} & \multicolumn{2}{|c|}{ Gini coefficient } \\
\hline & & & & & & & & Wage & Total Net \\
\hline & & & & & & & & Income & Income \\
\hline 0 & 2.063 & 0.2963 & 0.3604 & 0.6754 & 0.1425 & 0.03532 & 0.06514 & 0.561 & 0.496 \\
\hline 1 & 2.065 & 0.2992 & 0.3638 & 0.6797 & 0.1419 & 0.03676 & 0.06693 & 0.560 & 0.494 \\
\hline 2 & 2.066 & 0.3027 & 0.3671 & 0.6838 & 0.1412 & 0.03820 & 0.06871 & 0.559 & 0.492 \\
\hline
\end{tabular}

agents are subject to a more severe cold progression and governmental tax receipts increase by a higher percentage between period 0,1 , and 2 . Again, our finding for an inflation rate $\pi=5 \%$ is confirmed that aggregate savings and average labor supply increase during the course of cold progression. In addition, higher inflation reduces both the average labor supply and the inequality of the after-tax income distribution in the presence of cold progression. However, quantitative effects are very small in the case of the income distribution and both the Gini coefficient of the pre-tax wage distribution and the total net income distribution are only affected to a negligible extent. In particular, the Gini coefficient of total net income two periods after the most recent tax schedule adjustment 
Table 6: Cold progression, aggregate values and distribution for $\pi=10 \%$

\begin{tabular}{l|rrrrrrrrrrr}
\hline $\begin{array}{l}\text { year } t \text { after } \\
\text { tax code }\end{array}$ & & & & & & & & & & & \multicolumn{3}{c}{$\begin{array}{c}\text { Gini coefficient } \\
\text { Wage } \\
\text { adjustment }\end{array}$} & $K_{t}$ & & $\bar{l}_{t}$ & $N_{t}$ & $Y_{t}$ & $\bar{m}_{t}$ & $t_{r_{t}}$ & $T_{a x}$ Tet \\
Income & Income \\
\hline & & & & & & & & & & & \\
0 & 2.065 & 0.2943 & 0.3583 & 0.6731 & 0.0900 & 0.0348 & 0.0647 & 0.561 & 0.495 \\
1 & 2.068 & 0.2972 & 0.3616 & 0.8303 & 0.0898 & 0.6774 & 0.0676 & 0.560 & 0.492 \\
2 & 2.069 & 0.3002 & 0.3649 & 0.8353 & 0.0895 & 0.6815 & 0.0705 & 0.559 & 0.489 \\
\hline
\end{tabular}

Table 7: Cold progression, aggregate values and distribution for $\pi=5 \%$ Four-annual tax adjustments, $T B=4$

\begin{tabular}{|c|c|c|c|c|c|c|c|c|c|}
\hline \multirow{2}{*}{$\begin{array}{l}\text { year } t \text { after } \\
\text { tax code } \\
\text { adjustment }\end{array}$} & \multirow[b]{2}{*}{$K_{t}$} & \multirow[b]{2}{*}{$\bar{l}_{t}$} & \multirow[b]{2}{*}{$N_{t}$} & \multirow[b]{2}{*}{$Y_{t}$} & \multirow[b]{2}{*}{$\bar{m}_{t}$} & \multirow[b]{2}{*}{$t r_{t}$} & \multirow[b]{2}{*}{$\operatorname{Tax}_{t}$} & \multicolumn{2}{|c|}{ Gini coefficient } \\
\hline & & & & & & & & $\begin{array}{r}\text { Wage } \\
\text { Income }\end{array}$ & $\begin{array}{r}\text { Total Net } \\
\text { Income } \\
\end{array}$ \\
\hline 0 & 1.983 & 0.2774 & 0.3333 & 0.6334 & 0.1451 & 0.03148 & 0.05909 & 0.560 & 0.495 \\
\hline 1 & 1.986 & 0.2803 & 0.3370 & 0.6382 & 0.1445 & 0.03292 & 0.06089 & 0.560 & 0.494 \\
\hline 2 & 1.988 & 0.2834 & 0.3407 & 0.6429 & 0.1436 & 0.03438 & 0.06271 & 0.559 & 0.492 \\
\hline 3 & 1.989 & 0.2868 & 0.3446 & 0.6477 & 0.1426 & 0.03585 & 0.06453 & 0.557 & 0.490 \\
\hline
\end{tabular}

only drops from 0.492 to 0.489 .

As has been documented in section 2, the US government used to adjust its income tax schedule less frequently in the years prior to 1986 than in recent years. In order to analyze the effects of a less frequent income tax schedule adjustment and, hence, a longer duration of the cold progression, we extend the duration of the cold progression to $T B=4$ years (keeping the inflation rate at $\pi=5 \%$ ). As can be seen by inspection of Table 7 , agents decrease aggregate savings in this case by approximately $4.0 \%$. The fall in the average labor supply $\bar{l}_{t}$ is even more pronounced and amounts to approximately $6.3 \%$. Accordingly, the duration of the cold progression seems to be more important for the individual's labor supply and savings decision than the yearly increase in the marginal and average income tax rates. Notice further, that, again, even a longer period of cold progression does not have an important effect on the equality of income distribution. 


\section{Conclusion}

Cold progression has often been cited in the literature as one of the main reasons for an income-inequality reducing effect of (moderate) inflation. Both our empirical and our theoretical analysis support this hypothesis qualitatively. In our empirical analysis, furthermore, we find evidence that the inequality-minimizing inflation rate is in excess of $10 \%$. However, the quantitative effects of higher inflation on (income) inequality are negligible and economically insignificant. We, therefore, carefully conclude that income redistribution due to cold progression should not have been a major policy concern during the US postwar period. One important reason, of course, is that the US income tax schedule has also been characterized by a lower progression than tax income schedules of other countries, e.g. many continental European countries like, among others, Germany. For this reason, an interesting extension of our analysis would be the study of these countries.

In addition, we find that, in our theoretical model, the duration of the cold progression, i.e. the time period between two successive income tax schedule adjustments, is more important for equilibrium values of aggregate savings and average labor supply than the annual change in the tax rates due to cold progression. A shorter duration of cold progression results in higher equilibrium labor supply and output. Our results give support to possible benefits from the change in the US tax policy in the year 1986 as, by the mid 1980s, the US tax system became effectively inflation-indexed. 


\section{Appendix}

\subsection{US income tax: Changes of tax brackets and rates 1951-91}

The post-war changes of the US income tax schedule are summarized in Table 8 below. The main source of the entries in this table is IRS (2003) along with volumes of the US Major Tax Guide and the 'Individual Tax Statistics: Complete Report Publications' of the IRS, where these volumes were available.

In the first column of the table, the second date is the decisive one and gives the year of implementation of either a change of tax bracket boundaries $\left(T B B_{t}\right)$ or of regular income tax rates for fixed boundaries $\left(T R B_{t}\right)$ or of, at least, one of the former $\left(T T B_{t}=T B B_{t}+\right.$ $\left.T R B_{t}\right)$. Index $t$ denotes the specific year of change. The strength of adjustment is classified 'substantial' ('partial') in case of at least two (at most one) changing brackets (bracket) and/or at least two (at most one) adjusted tax rates (rate) for fixed boundaries. In this context, it is noteworthy that the partial changes for tax years 1968, 1969, and 1970 refer to the highest bracket's tax rate which was additionally burdened with a Vietnam War surcharge equal to $7.5 \%$ of tax for 1968, $10 \%$ of tax for 1969, and $2.5 \%$ of tax for 1970 . This surcharge did not alter any other than the highest bracket's rate.

For more detail on the major legislative changes enacted and realized during the period of observation the reader is referred to the brief outline in the text or to Auerbach and Feenberg (2000).

The changes of tax brackets reported in the following Table 8 are based on figures of boundaries for statutory taxable net income, i.e. income after subtracting deductions but before subtracting personal exemptions. Income in this definition still is the tax base for regular income tax, applicable to US citizens and residents. Deductions and provisions unique to nonresident aliens are not considered. The same holds for the tax rates underlying variable $T R B_{t}$. They also exclude the effect of tax liability reducing tax credits and refer to regular income tax, consisting in normal tax and surtax. ${ }^{14}$

\footnotetext{
${ }^{14}$ For tax years starting with 1954 , normal tax and surtax rates were, in effect, combined into a single rate structure; see IRS (2003), p. 325.
} 
Table 8. US individual income tax: Changes of tax brackets and rates 1951-91

\begin{tabular}{|c|c|c|c|c|c|}
\hline \multirow{2}{*}{$\begin{array}{c}\text { Consecutive } \\
\text { tax years }\end{array}$} & \multirow{2}{*}{$\begin{array}{l}\text { Adjustment } \\
\text { strength }\end{array}$} & \multirow{2}{*}{$\begin{array}{c}\text { Major legislative } \\
\text { change }\end{array}$} & \multicolumn{3}{|c|}{ Variables } \\
\hline & & & $T B B_{t}$ & $T R B_{t}$ & $T T B_{t}$ \\
\hline $50-51$ & substantial & - & 0 & 1 & 1 \\
\hline $51-52$ & substantial & - & 0 & 1 & 1 \\
\hline $53-54$ & substantial & - & 0 & 1 & 1 \\
\hline $63-64$ & substantial & Revenue Act & 1 & 1 & 1 \\
\hline $64-65$ & substantial & - & 1 & 1 & 1 \\
\hline $67-68$ & partial & - & 0 & 1 & 1 \\
\hline $68-69$ & partial & Reform Act & 0 & 1 & 1 \\
\hline $69-70$ & partial & - & 0 & 1 & 1 \\
\hline $76-77$ & substantial & - & 1 & 0 & 1 \\
\hline $78-79$ & substantial & - & 1 & 0 & 1 \\
\hline $80-81$ & substantial & Recovery Act & 0 & 1 & 1 \\
\hline $81-82$ & substantial & - & 1 & 1 & 1 \\
\hline $82-83$ & substantial & - & 1 & 1 & 1 \\
\hline $83-84$ & partial & - & 1 & 0 & 1 \\
\hline $84-85$ & substantial & - & 1 & 0 & 1 \\
\hline $85-86$ & substantial & Reform Act & 1 & 0 & 1 \\
\hline $86-87$ & substantial & - & 1 & 1 & 1 \\
\hline $87-88$ & substantial & - & 1 & 1 & 1 \\
\hline $88-89$ & substantial & - & 1 & 0 & 1 \\
\hline $89-90$ & substantial & - & 1 & 0 & 1 \\
\hline \multirow[t]{5}{*}{$90-91$} & substantial & - & 1 & 1 & 1 \\
\hline & & sum (pre-86): & 9 & 10 & 16 \\
\hline & & mean frequency (pre-86): & 4.00 & 3.60 & 2.25 \\
\hline & & $\operatorname{sum}(51-91)$ : & 14 & 14 & 21 \\
\hline & & mean frequency (51-91): & 2.93 & 2.93 & 1.95 \\
\hline
\end{tabular}

In general, there are four different (historical) sets of rates and brackets depending on the respective tax paying person(s): First, "income splitters," i.e. married taxpayers who "use the joint return filling status" and split their income for tax purposes in an effort 
to effectively double the width of their taxable (or net income) size brackets. Figures underlying the chronological categorization of Table 8 above are based on this set. Second, starting with 1952, a set of rates was introduced for "heads of households," i.e., for unmarried individuals who paid over half of the cost of maintaining a home for a qualifying person (e.g., a child or parent), or for certain married individuals who had lived apart from their spouses for the last six months of the tax year. This filling status was liberalized in 1970 and provides approximately half the advantages of the income-splitting. Third, the so-called "surviving spouse"-set of rates and brackets for which both, rates and taxable income brackets, are designed analogously to the ones of income-splitters. Finally, the remaining taxpayer-set is given for single persons. Since the late 1960s there is an effort of convergence of this set with the one of married couples filling jointly.

It is noteworthy that the 1986 Reform Act implemented during the Reagan-era hallmarks the start of a new period of lower rates and a reduced number of tax brackets. The latter along with the fact that by 1985 the US income tax system became effectively inflationindexed, led us to discriminate, in our empirical analysis, between the full sample period (1951-91) and the 1951-86 subsample.

\subsection{Computation}

The model of section 3 cannot be solved analytically, but only numerically. The solution algorithm is described by the following steps:

1. Parameterize the model. Let $T B$ denote the number of years between two adjustments of the nominal income tax schedule.

2. Make initial guesses of the law of motion for the aggregate capital stock $\left\{K_{0}, K_{1}, K_{2}, \ldots, K_{T B-1}\right\}$, aggregate effective labor $\left\{N_{0}, N_{1}, N_{2}, \ldots, N_{T B-1}\right\}$, aggregate real money $\left\{M / P_{0}, M / P_{1}, M / P_{2}, \ldots, M / P_{T B-1}\right\}$ and aggregate (=invidual) transfers $\left\{t r_{0}, t r_{1}, \ldots, t r_{T B-1}\right\}$.

3. Compute the values of $w_{t}$ and $r_{t}$ for $t=0,1, \ldots, T B-1$ that solve the firm's Euler equations. Compute the pension pen $_{t}$ so that the replacement rate of pensions with regard to net average labor income is equal to the empirical value. 
4. Compute the household's decision functions by solving the Euler equations.

5. Compute the distribution $\mu_{t}$ of the individual state variable $\{k, m, j\}$ by forward induction over age $j=1, \ldots, T+T^{R}$ for $t=0,1, \ldots, T B-1$.

6. Compute the aggregate capital stock $\left\{K_{0}, K_{1}, \ldots, K_{T B-1}\right\}$, aggregate effective labor $\left\{N_{0}, N_{1}, N_{2}, \ldots, N_{T B-1}\right\}$, aggregate real money $\left\{M / P_{0}, M / P_{1}, M / P_{2}, \ldots, M / P_{T B-1}\right\}$ and aggregate transfers $\left\{t r_{0}, t r_{1}, \ldots, t r_{T B-1}\right\}$. Update $\left\{K_{0}, K_{1}, \ldots, K_{T B-1}\right\}$, $\left\{N_{0}, N_{1}, N_{2}, \ldots, N_{T B-1}\right\},\left\{M / P_{0}, M / P_{1}, M / P_{2}, \ldots, M / P_{T B-1}\right\}$ and $\left\{t r_{0}, t r_{1}, \ldots, t r_{T B-1}\right\}$ and return to step 2 until convergence.

We discretize the state space $(k, m, z)$ using an equispaced grid over the capital stock $k$, the money balances $m$, and the individual productivity $z$. The upper grid points $k_{\max }=20.0$ and $m_{\max }=0.4$ are found to be non-binding. For the productivity $z$, the (five-point) grid ranges from $-2 \sigma_{y_{1}}$ to $2 \sigma_{y_{1}}$. The probability of having productivity shock $z_{1}$ in the first period of life is computed by integrating the area under the normal distribution. The transition probabilities are computed using the method of Tauchen (1986). As a consequence, the efficiency index $e(z, j)$ follows a finite Markov chain.

In step 4, a finite-time dynamic programming problem is to be solved. We use piecewise linear functions in order to approximate the policy functions $c_{t}(k, m, z, j), k_{t}^{\prime}(k, m, z, j)$, $m_{t}^{\prime}(k, m, z, j)$, and $l_{t}(k, m, z, j)$ between grid points. In particular, we solve the Euler functions (15)-(18) for given sequence of the aggregate capital stock $K_{t}$, aggregate effective employment $N_{t}$, and transfers $t r_{t}$.

As the household is born without any assets, his first-period wealth and his real money balances are zero. As a consequence, the value function would take the value $-\infty$ as $m_{1 t}=0$. For computational purposes, therefore, we slightly change the utility function and introduce a small constant $\psi$ into (11), $\tilde{u}=u(c, m+\psi, 1-l)$. 


\section{References}

Auerbach, A.J. and D. Feenberg, 2000, The Significance of Federal Taxes as Automatic Stabilizers, NBER Working Paper Series, Working Paper 7662.

Auerbach, A.J. and L. Kotlikoff, 1995, Macroeconomics: An Integrated Approach, SouthWestern College Publishing, Cincinnati, $\mathrm{OH}$.

Bach, G.L. and A. Ando, 1957, The Redistributional Effects of Inflation, Review of Economics and Statistics, vol. 39, 1-13.

Bach, G.L. and J.B. Stephenson, 1974, Inflation and the Redistribution of Wealth, Review of Economics and Statistics, vol. 56, 1-13.

Banerjee, A., J. Dolado, J. Galbraith, and D. Hendry, 1993, Cointegration, Error-Correction and the Econometric Analysis of Non-Stationary Data, Oxford University Press, Oxford.

Blinder, A.S. and H.Y. Esaki, 1978, Macroeconomic Activity and Income Distribution in the Postwar United States, Review of Economics and Statistics, vol. 60, 143-162.

Budd, E.C. and D.F. Seiders, 1971, The Impact of Inflation on the Distribution of Income and Wealth, American Economic Review Papers and Proceedings, vol. 61, 128-138.

Bulir, A. and A.-M. Gulde, 1995, Inflation and Income Distribution: Further Evidence on Empirical Links, International Monetary Fund Working Paper 95/86.

Castañeda, A., J. Díaz-Giménez, and J.-V. Ríos-Rull, 1999, Earnings and Wealth Inequality and Income Taxation: Quantifying the Trade-Offs of Switching to a Proportional Income Tax in the US, mimeo.

Deininger, K. and L. Squire, 1996, A New Data Set Measuring Income Inequality, World Bank Economic Review, No. 10, 565-591.

Díaz-Giménez, J., V. Quadrini, and J.V. Ríos-Rull, 1997, Dimensions of Inequality: Facts on the U.S. Distributions of Earnings, Income, and Wealth, Federal Reserve Bank of Minneapolis Quarterly Review 21, 3-21.

Galli, R. and R. van der Hoeven, 2001, Is Inflation Bad for Income Inequality: The Importance of the Initial Rate of Inflation, International Labor Organization Employment Paper 2001/29.

Gouveia, M. and R.O. Strauss, 1994, Effective Federal Individual Income Tax Functions: An Exploratory Empirical Analysis, National Tax Journal, vol. 47(2), 317-39.

Hansen, G., 1993, The cyclical and secular behavior of the labor input: comparing efficiency units and hours worked, Journal of Applied Econometrics 8, 71-80. 
Hodrick, R. and E. Prescott, 1997, Postwar U.S. Business Cycles: An Empirical Investigation, Journal of Money, Credit and Banking, vol. 29, 1-16.

Huggett, M., 1996, Wealth distribution in Life-Cycle Economies, Journal of Monetary Economics, vol. 17, 953-69.

İmrohoroğlu, A, İmrohoroğlu, S., and D.H. Joines, 1998, The Effect of Tax-favored Retirement Accounts on Capital Accumulation, American Economic Review, vol. 88, 749-68.

IRS, Internal Revenue Service, 2003, Selected Historical and Other Data Tables, Department of the Treasury, Washington.

Prescott, E., 1986, Theory Ahead of Business Cycle Measurement, Federal Reserve Bank of Minneapolis Quarterly Review, vol. 10, 9-22.

Ravn, M.O. and H. Uhlig, 2002, On Adjusting the Hodrick-Prescott Filter for the Frequency of Observations, Review of Economics and Statistics, vol. 84, 371-376.

Romer, C.D. and D.H. Romer , 1998, Monetary Policy and the Well-Being of the Poor, NBER Working Paper Series, Working Paper 6793.

Schultz, P.T., 1969, Secular Trends and Cyclical Behavior of Income Distribution in the United States, NBER Studies in Income and Wealth, vol. 33, 663-681.

Shorrocks, A.F., 1976, Income Mobility and the Markov Assumption, Economic Journal, vol. $86,566-578$.

Stokey, N., J.R. Lucas, and E.C. Prescott, 1989, Recursive methods in economic dynamics, Harvard University Press, Cambridge, Ma.

Tauchen, G., 1986, Finite State Markov-Chain Approximations To Univariate and Vector Autoregressions, Economics Letters, vol. 20, 177-81

Ventura, G., 1999, Flat tax reform: A quantitative exploration, Journal of Economic Dynamics and Control, vol. 23, 1425-1458.

Wolff, E.N., 1979, The Distributional Effects of the 1969-75 Inflation on Holdings of Household Wealth in the United States, Review of Income and Wealth, vol. 25, 195207. 


\title{
CESifo Working Paper Series
}

\author{
(for full list see www.cesifo.de)
}

884 Eytan Sheshinski, Note on the Optimum Pricing of Annuities, March 2003

885 Paul De Grauwe and Magdalena Polan, Globalisation and Social Spending, March 2003

886 F. van der Ploeg, Do Social Policies Harm Employment and Growth?, March 2003

887 Mirjam van Praag, Initial Capital Constraints Hinder Entrepreneurial Venture Performance: An empirical analysis, March 2003

888 Bernard Steunenberg, Coordinating Sectoral Policymaking: Searching for Countervailing Mechanisms in the EU Legislative Process, March 2003

889 Eytan Sheshinski, Optimum Delayed Retirement Credit, March 2003

890 Frederick van der Ploeg, Rolling Back the Public Sector - Differential effects on employment, investment and growth, March 2003

891 Paul De Grauwe and Marc-Alexandre Sénégas, Monetary Policy in EMU when the Transmission is Asymmetric and Uncertain, March 2003

892 Steffen Huck and Kai A. Konrad, Strategic Trade Policy and the Home Bias in Firm Ownership Structure, March 2003

893 Harry Flam, Turkey and the EU: Politics and Economics of Accession, March 2003

894 Mathias Hoffmann and Ronald MacDonald, A Re-examination of the Link between Real Exchange Rates and Real Interest Rate Differentials, March 2003

895 Badi H. Baltagi, Espen Bratberg, and Tor Helge Holmås, A Panel Data Study of Physicians' Labor Supply: The Case of Norway, March 2003

896 Dennis C. Mueller, Rights and Citizenship in the European Union, March 2003

897 Jeremy Edwards, Gains from Trade in Tax Revenue and the Efficiency Case for Trade Taxes, March 2003

898 Rainer Fehn and Thomas Fuchs, Capital Market Institutions and Venture Capital: Do They Affect Unemployment and Labour Demand?, March 2003

899 Ronald MacDonald and Cezary Wójcik, Catching Up: The Role of Demand, Supply and Regulated Price Effects on the Real Exchange Rates of Four Accession Countries, March 2003 
900 R. Selten, M. Schreckenberg, T. Pitz, T. Chmura, and S. Kube, Experiments and Simulations on Day-to-Day Route Choice-Behaviour, April 2003

901 Stergios Skaperdas, Restraining the Genuine Homo Economicus: Why the Economy Cannot be Divorced from its Governance, April 2003

902 Yin-Wong Cheung, Menzie D. Chinn, and Antonio Garcia Pascual, What Do We Know about Recent Exchange Rate Models? In-Sample Fit and Out-of-Sample Performance Evaluated, April 2003

903 Mika Widgrén, Enlargements and the Principles of Designing EU - Decision-Making Procedures, April 2003

904 Phornchanok Cumperayot, Dusting off the Perception of Risk and Returns in FOREX Markets, April 2003

905 Kai A Konrad, Inverse Campaigning, April 2003

906 Lars P. Feld and Stefan Voigt, Economic Growth and Judicial Independence: Cross Country Evidence Using a New Set of Indicators, April 2003

907 Giuseppe Bertola and Pietro Garibaldi, The Structure and History of Italian Unemployment, April 2003

908 Robert A.J. Dur and Otto H. Swank, Producing and Manipulating Information, April 2003

909 Christian Gollier, Collective Risk-Taking Decisions with Heterogeneous Beliefs, April 2003

910 Alexander F Wagner, Mathias Dufour, and Friedrich Schneider, Satisfaction not Guaranteed - Institutions and Satisfaction with Democracy in Western Europe, April 2003

911 Ngo Van Long, Raymond Riezman, and Antoine Soubeyran, Trade, Wage Gaps, and Specific Human Capital Accumulation, April 2003

912 Andrea Goldstein, Privatization in Italy 1993-2002: Goals, Institutions, Outcomes, and Outstanding Issues, April 2003

913 Rajshri Jayaraman and Mandar Oak, The Signaling Role of Municipal Currencies in Local Development, April 2003

914 Volker Grossmann, Managerial Job Assignment and Imperfect Competition in Asymmetric Equilibrium, April 2003

915 Christian Gollier and Richard Zeckhauser, Collective Investment Decision Making with Heterogeneous Time Preferences, April 2003

916 Thomas Moutos and William Scarth, Some Macroeconomic Consequences of Basic Income and Employment Subsidies, April 2003 
917 Jan C. van Ours, Has the Dutch Miracle Come to an End?, April 2003

918 Bertil Holmlund, The Rise and Fall of Swedish Unemployment, April 2003

919 Bernd Huber and Marco Runkel, Optimal Design of Intergovernmental Grants under Asymmetric Information, April 2003

920 Klaus Wälde, Endogenous Business Cycles and Growth, April 2003

921 Ramon Castillo and Stergios Skaperdas, All in the Family or Public? Law and Appropriative Costs as Determinants of Ownership Structure, April 2003

922 Peter Fredriksson and Bertil Holmlund, Improving Incentives in Unemployment Insurance: A Review of Recent Research, April 2003

923 Bernard M.S. van Praag and Adam S. Booij, Risk Aversion and the Subjective Time Discount Rate: A Joint Approach, April 2003

924 Yin-Wong Cheung, Kon S. Lai, and Michael Bergman, Dissecting the PPP Puzzle: The Unconventional Roles of Nominal Exchange Rate and Price Adjustment, April 2003

925 Ugo Trivellato and Anna Giraldo, Assessing the 'Choosiness' of Job Seekers. An Exploratory Approach and Evidence for Italy, April 2003

926 Rudi Dornbusch and Stanley Fischer, International Financial Crises, April 2003

927 David-Jan Jansen and Jakob de Haan, Statements of ECB Officials and their Effect on the Level and Volatility of the Euro-Dollar Exchange Rate, April 2003

928 Mario Jametti and Thomas von Ungern-Sternberg, Assessing the Efficiency of an Insurance Provider - A Measurement Error Approach, April 2003

929 Paolo M. Panteghini and Guttorm Schjelderup, Competing for Foreign Direct Investments: A Real Options Approach, April 2003

930 Ansgar Belke, Rainer Fehn, and Neil Foster, Does Venture Capital Investment Spur Employment Growth?, April 2003

931 Assar Lindbeck, Sten Nyberg, and Jörgen W. Weibull, Social Norms and Welfare State Dynamics, April 2003

932 Myrna Wooders and Ben Zissimos, Hotelling Tax Competition, April 2003

933 Torben M. Andersen, From Excess to Shortage - Recent Developments in the Danish Labour Market, April 2003

934 Paolo M. Panteghini and Carlo Scarpa, Irreversible Investments and Regulatory Risk, April 2003 
935 Henrik Jacobsen Kleven and Claus Thustrup Kreiner, The Marginal Cost of Public Funds in OECD Countries. Hours of Work Versus Labor Force Participation, April 2003

936 Klaus Adam, George W. Evans, and Seppo Honkapohja, Are Stationary Hyperinflation Paths Learnable?, April 2003

937 Ulrich Hange, Education Policy and Mobility: Some Basic Results, May 2003

938 Sören Blomquist and Vidar Christiansen, Is there a Case for Public Provision of Private Goods if Preferences are Heterogeneous? An Example with Day Care, May 2003

939 Hendrik Jürges, Kerstin Schneider, and Felix Büchel, The Effect of Central Exit Examinations on Student Achievement: Quasi-experimental Evidence from TIMSS Germany, May 2003

940 Samuel Bentolila and Juan F. Jimeno, Spanish Unemployment: The End of the Wild Ride?, May 2003

941 Thorsten Bayindir-Upmann and Anke Gerber, The Kalai-Smorodinsky Solution in Labor-Market Negotiations, May 2003

942 Ronnie Schöb, Workfare and Trade Unions: Labor Market Repercussions of Welfare Reform, May 2003

943 Marko Köthenbürger, Tax Competition in a Fiscal Union with Decentralized Leadership, May 2003

944 Albert Banal-Estañol, Inés Macho-Stadler, and Jo Seldeslachts, Mergers, Investment Decisions and Internal Organisation, May 2003

945 Kaniska Dam and David Pérez-Castrillo, The Principal-Agent Matching Market, May 2003

946 Ronnie Schöb, The Double Dividend Hypothesis of Environmental Taxes: A Survey, May 2003

947 Erkki Koskela and Mikko Puhakka, Stabilizing Competitive Cycles with Distortionary Taxation, May 2003

948 Steffen Huck and Kai A. Konrad, Strategic Trade Policy and Merger Profitability, May 2003

949 Frederick van der Ploeg, Beyond the Dogma of the Fixed Book Price Agreement, May 2003

950 Thomas Eichner and Rüdiger Pethig, A Microfoundation of Predator-Prey Dynamics, May 2003

951 Burkhard Heer and Bernd Süssmuth, Cold Progression and its Effects on Income Distribution, May 2003 